\title{
Overlap of latent pathogens in the Botryosphaeriaceae on a native and agricultural host
}

James W. M. Mehl ${ }^{\mathrm{a}}$, Bernard Slippers ${ }^{\mathrm{b}, *}$, Jolanda Roux ${ }^{\mathrm{c}}$ and Michael J. Wingfield ${ }^{\mathrm{a}}$

aDepartment of Microbiology and Plant Pathology, DST/NRF Centre of Excellence in Tree Health Biotechnology (CTHB), Forestry and Agricultural Biotechnology Institute (FABI), University of Pretoria,

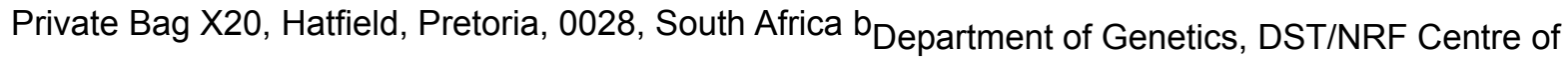
Excellence in Tree Health Biotechnology (CTHB), Forestry and Agricultural Biotechnology Institute (FABI), University of Pretoria, Private Bag X20, Hatfield, Pretoria, 0028, South Africa

CDepartment of Plant Science, DST/NRF Centre of Excellence in Tree Health Biotechnology (CTHB), Forestry and Agricultural Biotechnology Institute (FABI), University of Pretoria, Private Bag X20, Hatfield, Pretoria, 0028, South Africa

*E-mail: bernard.slippers@fabi.up.ac.za (for correspondence)

\section{ABSTRACT}

Some species of the Botryosphaeriaceae are capable of infecting a broad range of host plants. We studied the species diversity of Botryosphaeriaceae associated with marula (Sclerocarya birrea subsp. caffra, Anacardiaceae) trees in South Africa over two seasons, as well as species common to both $S$. birrea and adjacent mango (Mangifera indica, Anacardiaceae) trees in a subset of sites. Gene flow amongst populations of Botryosphaeriaceae shared on these tree species was tested using microsatellite markers. Twelve species were identified from S. birrea and eleven species were found on $M$. indica trees. From isolations done in 2006, the dominant species on S. birrea was Neofusicoccum vitifusiforme, while $N$. parvum was the dominant species isolated from $M$. indica. Neofusicoccum parvum was dominant in isolations from both hosts in 2012. Isolates of Botryosphaeria fabicerciana, Lasiodiplodia mahajangana, $L$. pseudotheobromae, L. theobromae, N. mediterraneum and N. umdonicola were also collected from both hosts. Population genetic analyses on isolates of $N$. parvum suggested that three populations were present, each comprising isolates from both hosts. There was significant gene flow between $N$. parvum populations on these hosts. This ability to infect multiple hosts and to migrate amongst them facilitates the establishment and spread of species and genotypes of the Botryosphaeriaceae, such as N. parvum, in new areas. 
Keywords: Botryosphaeriales; Anacardiaceae; host range; endophytes; marula; mango

\section{Introduction}

Fungi in the Botryosphaeriaceae are well known as endophytic and opportunistic pathogens of woody plants. These fungi infect plants via wounds or through natural plant openings such as buds, lenticels and stomata (Slippers and Wingfield 2007). Many species in the family have a wide range of plant hosts, including commercial fruit crops (Chen et al. 2014; Slippers et al. 2005; van Niekerk et al. 2004), forest trees (Burgess et al. 2006b; Slippers et al. 2009), and plants in native woody ecosystems (Jami et al. 2014; Mehl et al. 2011; Pavlic et al. 2007). These fungi occur in healthy plant tissues as latent pathogens and persist endophytically until stress occurs, after which disease symptoms can manifest (Slippers and Wingfield 2007).

The spores (sexual and asexual) of Botryosphaeriaceae are principally dispersed by wind or rain splash (Swart et al. 1987; Mehl et al. 2013). Since many of the Botryosphaeriaceae have broad host ranges (Jami et al. 2014; Slippers and Wingfield 2007), these fungi can spread to and infect both related and unrelated plants. There are many examples of interhost exchanges of the Botryosphaeriaceae, and these include those amongst and between native and non-native trees. For example, species of the Botryosphaeriaceae have been shown to move between trees in native stands of Eucalyptus (Myrtaceae) and adjacent plantations of these trees (Burgess et al. 2006b), between native waterberry trees (Syzygium cordatum; Myrtaceae) and related eucalypt plantations (Myrtaceae) (Pavlic et al. 2007), from Pinus resinosa windbreaks to pine nurseries (Stanosz et al. 2007), among various tree hosts in the Casuarinaceae, Cupressaceae, Fabaceae, Myrtaceae, Proteaceae, Santalaceae (Sakalidis et al. 2011), and among native Terminalia spp. (Combretaceae) and between these trees and Theobroma cacao (Malvaceae) (Begoude et al. 2012), amongst others.

The ability of fungi such as the Botryosphaeriaceae to infect multiple hosts, increases the threat that they pose as potential economic and ecological important pathogens of native and cultivated trees globally. In South Africa, two related tree species, the native Sclerocarya birrea subsp. caffra known locally as marula, and non-native mango (Mangifera indica), in the Anacardiaceae commonly occur in close proximity to each other. 
Mangifera indica is native to India and is an important subtropical crop cultivated in various countries, including South Africa (Snyman 1998). Species of the Botryosphaeriaceae are associated with two important diseases on M. indica globally. These include stem-end rot on fruit which occurs when these fungi gain entrance via the peduncle (Johnson and Kotzé 1994) causing disease when fruits ripen or are harvested (Menge and Ploetz 2003). The Botryosphaeriaceae can also infect $M$. indica via wounds that occur during fruit abscission, pruning or hand-picking, or via lenticels on the fruit surface (Menge and Ploetz 2003). Another important disease known as blossom blight occurs when Botryosphaeriaceae infect the M. indica inflorescences (Ploetz 2003).

Sclerocarya birrea is an iconic native African tree with a broad geographic range that extends from Senegal through Ethiopia to South Africa and into Angola and Namibia (Peters 1988). It is extensively used by local communities and is prominent in the production of well-known liqueur (Shackleton et al. 2002). Little is known regarding the diseases of $S$. birrea but a few fungi (7 species) have been recorded, and none of these include the Botryosphaeriaceae. This is likely due to a very limited number of studies that have considered the fungi associated with this tree species (Crous et al. 2000; Doidge 1950; Farr and Rossman 2016).

The aims of this study were to determine which species of the Botryosphaeriaceae infect S. birrea trees in South Africa. Since S. birrea and M. indica trees are taxonomically related and grow in close proximity to each other, $M$. indica trees were also sampled. This was principally to determine whether species of the Botryosphaeriaceae might be common to both trees. A subsequent aim was to seek evidence of gene flow in specific species of the Botryosphaeriaceae that occur on both S. birrea and M. indica.

\section{Materials and Methods}

\subsection{Sample collections and isolations}

Two sample collections were made in 2006 and 2012. In 2006, branches from Sclerocarya birrea trees were sampled at three locations: Skukuza/Pretoriuskop area in the Kruger National Park (Mpumalanga Province), Hans Merensky estate close to Hoedspruit 
(Limpopo Province), and Lakelands, Mfolozi Village in the KwaZulu-Natal Province. One hundred and forty four branches from 130 Mangifera indica trees were also sampled at the Hans Merensky estate from two orchards; one an orchard where trees were chemically treated and a second where trees were organically grown. For the former, 15 branches were sampled from the central tree and then four trees in a $10 \mathrm{~m}$ diagonal to this tree were sampled (one branch each). This was followed by sampling one branch from 15 trees in the vicinity of each of the four trees, making up 79 branches from 65 trees. In the organic orchard, the same strategy was used except that a single branch was sampled from the central tree, resulting in 65 branches sampled. In 2012, three to five branches per tree were collected from neighbouring S. birrea and nearby $M$. indica trees alongside the road between Hoedspruit and Klaserie (Limpopo Province). Two sites along this road, less than $10 \mathrm{~km}$ apart, were sampled and these included six M. indica trees and three S. birrea trees at the first site, and $13 \mathrm{M}$. indica trees and $14 \mathrm{~S}$. birrea trees at the second site.

Isolations were made from discoloured pith tissue, leaf samples, edges of visible lesions, and from asymptomatic twigs following the method described by Pavlic et al. (2004). Isolations were made one and four weeks after sampling for the 2006 samples and two, four, six, and eight weeks after sampling for the 2012 samples. Resulting cultures were purified and isolates resembling the Botryosphaeriaceae retained for further study.

Isolates from the 2006 collections were transferred to $2 \%$ water agar (Biolab, South Africa) overlaid with sterile pine needles and incubated under near ultraviolet light (Smith et al. 1996) at $25^{\circ} \mathrm{C}$. Fruiting structures were sectioned and spores examined microscopically to group isolates into genera. Isolates collected in 2012 were purified using single hyphal tip transfers (Mehl et al. 2011). Cultures used in this study have been maintained in the culture collection (CMW) of the Forestry and Agricultural Biotechnology Institute $(\mathrm{FABI})$ at the University of Pretoria, Pretoria, South Africa.

\subsection{DNA extractions}

DNA was extracted from all isolates collected in both 2006 and 2012 for identification using DNA sequence data comparisons. For the 2006 isolates, DNA was extracted using the method of van Wyk et al. (2006) while the method of Wright et al. (2010), with the exception that DNA pellets were suspended in $50 \mu \mathrm{l} \mathrm{TE}$ buffer, was used for the 2012 
isolates.

\subsection{PCR and DNA sequencing reactions}

Isolate identification was done using data from the ITS rDNA (which included the ITS1, 5.8S nrRNA gene, and ITS2), translation elongation factor $1 \alpha$ (tef1), and $\beta$-tubulin-2 (tub2) loci. Primer sets ITS1 and ITS4 (White et al. 1990), EF1-728F and EF1-986R (Carbone and Kohn 1999) and EF1F and EF2R (Jacobs et al. 2004), and Bt-2a and Bt-2b (Glass and Donaldson 1995) were used to amplify the ITS rDNA, tef1, and tub2 loci, respectively.

For PCR amplifications, 5-30 ng template DNA was combined with one of three different mixtures to successfully amplify loci for DNA sequencing. The first mix consisted of $1.5 \times$ FastStart PCR buffer (with 3 mM added $\mathrm{MgCl}_{2}$ ) (Roche Molecular Biochemicals, Almeda, California), $0.2 \mu \mathrm{M}$ of each primer, $2.5 \mu \mathrm{M}$ of each dNTP, and $0.5 \mathrm{U}$ FastStart Taq Polymerase (Roche). The second mix consisted of $1 \times$ KAPA Taq Buffer A (KAPA Biosystems, Cape Town, South Africa), $0.4 \mu \mathrm{M}$ of each primer, $2.5 \mathrm{mM}$ of each dNTP, and 1 U KAPA Taq Polymerase (KAPA Biosystems). The third mix consisted of $1 \times$ MyTaq Reaction Buffer (Bioline, Germany), $0.2 \mathrm{mM}$ of each primer, and 0.5 U MyTaq DNA Polymerase (Bioline). Sterile Sabax water (Adcock Ingram, Johannesburg, South Africa) was added to adjust mixtures to a volume of $25 \mu \mathrm{l}$ per reaction.

One of two PCR cycling conditions were used to successfully amplify loci of isolates collected. The first set of cycling conditions consisted of an initial denaturation step of 95 ${ }^{\circ} \mathrm{C}$ for $2 \mathrm{~min}$ followed by 40 cycles of $95^{\circ} \mathrm{C}$ for $20 \mathrm{~s}, 55^{\circ} \mathrm{C}$ for $30 \mathrm{~s}$ and $72^{\circ} \mathrm{C}$ for $1 \mathrm{~min} 30$ $\mathrm{s}$, followed by a final extension step of $72^{\circ} \mathrm{C}$ for $7 \mathrm{~min}$. PCR products were visualized using $1.5 \%$ agarose-ethidium bromide gels run in $1 \times$ TAE buffer and product sizes estimated using a Lambda DNA/EcoRI + HindIII marker 3 (Fermentas Life Sciences, USA). The second set of PCR cycling conditions and the method used to visualize products were the same as those described by Mehl et al. (2014).

PCR products were purified and sequenced using the methods described by Mehl et al. (2011). Sequences generated during this study were deposited in GenBank (Table 1) and datasets and phylogenetic trees submitted to TreeBase (S19055 http://purl.org/phylo/treebase/phylows/study/TB2:S19055?x-access- 


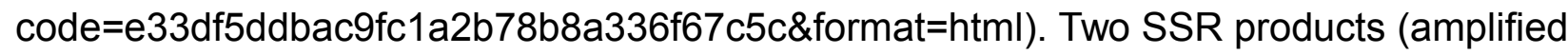
using unlabelled primers) representing the same individual allele per locus were also purified and sequenced to confirm scores. Sequences were visually assessed and edited using MEGA v. 5 (Tamura et al. 2011) and additional sequences sourced from GenBank as required.

\subsection{Phylogenetic analyses}

Isolates were identified by subjecting their respective DNA sequences to BLASTn analysis. To confirm identifies, sequence datasets were constructed and phylogenetic analyses made. Species were represented by sequences from the ex-type strain and one or two exparatype strains.

Two groups of sequence datasets were generated in this study. The first consisted of all Botryosphaeriaceae species with a representative group of isolates from each species, and a selection of isolates from the Neofusicoccum parvum-ribis complex. For this first group, only sequence data for the ITS and tef1 loci were generated and analyzed. Two isolates of Melanops tulasnei (Phillips and Alves 2009) were used as outgroup taxa for these analyses. The second group consisted of isolates and species identified as members of the N. parvum-ribis complex. For the latter group, sequence datasets for ITS, tef1, and tub2 were generated and analyzed, with no outgroup taxon selected. In all cases, sequence datasets were aligned using MAFFT v. 6 (Katoh and Toh 2008) by applying the G-INS-i algorithm and checked visually. Maximum parsimony (MP), and maximum likelihood (ML) phylogenetic analyses were undertaken on the datasets for individual loci sequenced as well as on the combined dataset. MP analyses were done in PAUP* (Phylogenetic Analysis Using Parsimony) v. 4.0b10 (Swofford 2003) with the same settings used by Mehl et al. (2014). Additionally, a partition homogeneity test (PHT) was done for each combined dataset with the same settings as those used by Mehl et al (2014). For ML analyses, datasets were parsed through jModelTest v. 2.1.3 (Darrida et al. 2012) with the corrected Akaike Information Criterion selected to determine the best nucleotide substitution model. Analyses of each dataset, as well as the combined dataset were then done using PhyML v. 3.0.1 (Guindon et al. 2010) with the relevant model parameters selected. Bootstrap analyses were used to determine the robustness of trees resulting from the MP and ML analyses. Trees were visualized using TreeGraph v. 2 (Stöver and 
Müller 2010).

\subsection{SSR amplifications}

Genotypes of Neofusicoccum parvum isolates were determined using eight microsatellite (SSR) markers (Slippers et al. 2004). Loci were amplified with primers labelled with the same dyes as those used by Slippers et al. (2004). In cases where amplification proved unsuccessful, sequence data were generated using unlabelled primers. Two reaction mixtures were used. The first mix consisted of $\sim 20 \mathrm{ng}$ template DNA, $1.5 \times$ PCR buffer (with $3 \mathrm{mM}$ added $\mathrm{MgCl}_{2}$ ), $1.25 \mu \mathrm{M}$ of each dNTP, $0.1 \mu \mathrm{M}$ of each primer, and $0.2 \mathrm{U}$ FastStart Taq Polymerase. The second mix consisted of $1 \times$ MyTaq Reaction Buffer, 0.2 $\mu \mathrm{M}$ of each primer, and 0.5 U MyTaq DNA Polymerase. The PCR cycling conditions and method of visualization of the SSR products were the same as those used by Mehl et al. (2014). Dilutions (1:25) were made of SSR products in sterile Sabax water and $1 \mu$ of this mix was combined with $10 \mu \mathrm{l}$ of a suspension of LIZ-labelled Genescan 500 size standard

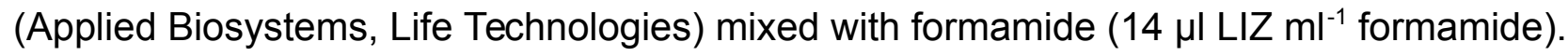
The products were then run on an Applied Biosystems 3500 Genetic Analyzer. Alleles were scored using GeneMapper ${ }^{\circledR}$ Software (Applied Biosystems).

\subsection{Population genetic analyses}

Isolates collected in 2012 and identified as Neofusicoccum parvum, a species common to both Sclerocarya birrea and Mangifera indica, were grouped according to their host in the analyses. Null alleles were treated as missing data. Population subdivision was tested using the Bayesian clustering algorithm implemented in STRUCTURE v. 2.3.4 (Hubisz et al. 2009) on the dataset for all isolates. Burnin was set at 300000 and the number of MCMC repeats done after burnin was set at 900 000. An admixture model was selected, allele frequencies were set as correlated and lambda was set at one. Twenty iterations were done for each prior of $K=1$ to $K=10$. Results were then parsed through STRUCTURE HARVESTER (Earl and vonHoldt 2012) and the DeltaK (Evanno et al. 2005) output used to identify the number of potential subpopulations. To confirm the result, K-means clustering ( $\mathrm{K}=1$ to $\mathrm{K}=10$ ) was done in GenoDive v. $2 \mathrm{~b} 24$ (Meirmans and van Tienderen 2004) based on both allele frequencies and an Analysis of Molecular Variance (AMOVA) using 50000 steps and 20 replicates. 
The data were clone-corrected by identifying identical genotypes using the Assign Clones option in GenoDive. Clone correction was done because the presence of clonal genotypes is known to affect several measures of population statistics (Halkett et al. 2005). Genotypic diversity was calculated prior to clone-correction, also using GenoDive. Non-random association or linkage disequilibrium of loci in the combined dataset of isolates from $S$. birrea and $M$. indica was determined using the Index of Association $\left(\mathrm{I}_{\mathrm{A}}\right)$ and $\mathrm{rBarD}$ and calculated using MultiLocus v. 1.3b (Agapow and Burt 2001). To determine where most of the variation originated within the dataset, an AMOVA (Excoffier et al. 1992) test was done in GenoDive. Allelic frequencies, expected gene diversity, and measures of population differentiation ( $F_{\mathrm{ST}}$, Hedrick's $G_{\text {ST }}$ and Jost's $D_{\mathrm{EST}}$ ) were computed, also using GenoDive.

Gene flow was determined using two methods. The private alleles method computes the effective number of migrants $(\mathrm{Nm})$ based on rare alleles present (Barton and Slatkin 1986), and is implemented in the Genepop web service (Rousset 2008). A second method (implemented in BIMr) uses Bayesian Inference to estimate migration rates from the previous generation to that sampled while factoring in environmental factors that can influence these rates (Faubet and Gaggiotti 2008). For the second method, ten iterations were done with burnin set at 300000 followed by 900000 runs.

\section{Results}

\subsection{Isolate collections}

Sixty-two isolates were obtained from the Sclerocarya birrea samples collected in 2006 and identified based on sequence data (Fig. 1, Table S1). Thirty-eight of these originated from samples collected in the Kruger National Park (KNP), 23 from Lakelands, Mfolozi Village, and one from the Hans Merensky estate. Most isolates produced Neofusicoccumlike conidia, but some had pigmented conidia typical of Lasiodiplodia species. One hundred and forty-one isolates resulted from the Mangifera indica samples collected from the Hans Merensky estate from the 144 branches sampled.

Isolations from samples collected in September 2012 from the Hoedspruit area resulted in a collection of 196 isolates, of which 34 were obtained from branches of the 17 S. birrea 
trees sampled and 163 from the 19 M. indica trees sampled (Fig. 1, Table S1).

\subsection{DNA sequence analyses and species identifications}

Sequence datasets generated for the ITS, tef1, and tub2 loci were analyzed both individually and in combination. For the first group, the ITS dataset consisted of 540 characters (153 parsimony informative, 374 constant, 13 parsimony uninformative), and yielded 194,910 most parsimonious trees $(T L=270, C l=0.73, R I=0.953, R C=0.696)$. The model selected for ML analysis was TPM1 uf $(\gamma=0.295)$. The tef1 dataset consisted of 309 characters (191 parsimony informative, 107 constant, 11 parsimony uninformative), and yielded 738,939 most parsimonious trees $(\mathrm{TL}=469, \mathrm{Cl}=0.663, \mathrm{RI}=0.943, \mathrm{RC}=$ 0.625). The model selected for $M L$ analysis was $H K Y(t i / t v=1.534, y=0.789)$. The combined analysis consisted of 849 characters (344 parsimony informative, 481 constant, 24 parsimony uninformative), and yielded 1,034,389 most parsimonious trees ( $T L=756$, $\mathrm{Cl}=0.672, \mathrm{RI}=0.943, \mathrm{RC}=0.633)$. The model TVM $(\mathrm{y}=0.679, \mathrm{p}$-inv $=0.261)$ was selected for ML analysis. The PHT value was 0.001 .

For the second group of isolates and species that grouped within the Neofusicoccum parvum-ribis complex, the ITS dataset consisted of 502 characters (4 parsimony informative, 490 constant, 8 parsimony uninformative), and yielded a single most parsimonious tree $(T L=4, C l=1, R I=1, R C=1)$. The model selected for $M L$ analysis was $\mathrm{K} 80$ (ti/tv = 3.014). The tef1 dataset consisted of 266 characters ( 7 parsimony informative, 257 constant, 2 parsimony uninformative), and yielded four most parsimonious trees $(T L=7, C l=1, R I=1, R C=1)$. The model selected for $M L$ analysis was $H K Y(t i / t v=$ 8.088). The tub2 dataset consisted of 420 characters ( 9 parsimony informative, 404 constant, 7 parsimony uninformative), and yielded a single most parsimonious tree $(\mathrm{TL}=$ $10, \mathrm{Cl}=0.9, \mathrm{RI}=0.974, \mathrm{RC}=0.876)$. The model selected for $\mathrm{ML}$ analysis was $\mathrm{HKY}(\mathrm{ti} / \mathrm{tv}=$ 1.855). The combined analysis consisted of 1188 characters (20 parsimony informative, 1 151 constant, 17 parsimony uninformative), and yielded two most parsimonious trees (TL $=27, \mathrm{Cl}=0.741, \mathrm{RI}=0.915, \mathrm{RC}=0.678)$. The model HKY (ti/tv $=3.470, \mathrm{y}=0.023)$ was selected for ML analysis. The PHT value was 0.001 .

Tree topologies emerging from the MP and ML analyses were similar for each analysis. For the first group, differences occurred where some clades for Lasiodiplodia species 
collapsed in the ITS dataset (Fig. S1), but were easily resolved when analyzing tef1 (Fig. S2). While the two sequence datasets were separately interpreted given the results of the PHT tests, both datasets were combined to illustrate all species identified (Fig. 2) as the incongruence reflected the interpretation of the individual trees. For the second group, isolates grouped into distinct clades representing species, but two subclades (based on the tef1 and tub2 analyses) emerged for isolates grouping together as Neofusicoccum parvum. These sub-clades were not evident when analyzing the ITS dataset. All three gene phylogenies are shown along with the combined phylogeny resulting from concatenation of the three datasets (Fig. 3). Isolates collected in both 2006 and 2012 grouped with known species of the Botryosphaeriaceae, in five genera, specifically Botryosphaeria, Diplodia, Lasiodiplodia, Neofusicoccum, and Pseudofusicoccum.

Seven species of Botryosphaeriaceae were obtained from the 2006 isolations made from Sclerocarya birrea trees (Table S1, Fig. 1). The dominant taxon emerging from these isolations was Neofusicoccum vitifusiforme that occurred at all three sites (KNP: $n=36$, Lakelands: $n=9$, Hans Merensky: $n=1)$. Neofusicoccum mediterraneum was the only other species isolated from the KNP $(n=8)$ and Lakelands $(n=1)$. Single isolates of Lasiodiplodia theobromae were obtained from the Hans Merensky and Lakelands samples. The remaining four species, including Diplodia allocellula $(\mathrm{n}=2)$, Lasiodiplodia crassispora $(\mathrm{n}=1)$, Lasiodiplodia gonubiensis $(\mathrm{n}=3)$ and Lasiodiplodia iraniensis $(\mathrm{n}=8)$, were isolated exclusively from the Lakelands samples.

Eight species of Botryosphaeriaceae were isolated from the 2006 Mangifera indica samples. The most common species was $N$. parvum $(n=114)$. Other species obtained included Neofusicoccum umdonicola $(n=13)$, Neofusicoccum kwambonambiense $(n=6)$, Botryosphaeria fabicerciana $(n=2)$, Lasiodiplodia pseudotheobromae $(n=2)$, Lasiodiplodia theobromae $(n=2)$, Lasiodiplodia mahajangana $(n=1)$, and Neofusicoccum australe $(n=1)$.

Five species of Botryosphaeriaceae were recovered from the 2012 isolations made from $S$. birrea trees in the Hoedspruit area. Isolates of $N$. parvum $(n=29)$ were most common. In addition, two isolates of $N$. umdonicola and single isolates of $B$. fabicerciana, $L$. mahajangana and L. pseudotheobromae were also identified from these samples. 
indica trees in the Hoedspruit area. Again, the most commonly isolated taxon was $N$. parvum $(\mathrm{n}=137)$. Isolates of $N$. umdonicola $(\mathrm{n}=12), N$. kwambonambiense $(\mathrm{n}=8), B$. fabicerciana $(n=3)$, Pseudofusicoccum olivaceum $(n=2)$ and $N$. mediterraneum $(n=1)$ were also identified from these samples.

Six species of Botryosphaeriaceae were common to both S. birrea and M. indica trees sampled in 2012. These included B. fabicerciana, L. mahajangana, L. theobromae, $N$. mediterraneum, N. parvum, and $N$. umdonicola. Low isolate numbers precluded all, except $N$. parvum from further study. Since $N$. parvum was most common on both tree species, isolates were further studied using microsatellite markers.

\subsection{Population genetic analyses on N. parvum}

A set of 94 Neofusicoccum parvum isolates (29 from Sclerocarya birrea and 65 from Mangifera indica) were selected. These were representative of both sites where branches were collected, and included isolates obtained at each of the four timepoints (two, four, six, and eight weeks) when isolations were made. Of the eight SSR loci tested, two (BotF15 and BotF37) were monomorphic and not used. Eight allele variants were detected in one locus (BotF17), seven variants in a second locus (BotF35), three variants in two other loci (BotF11 and BotF18), and two variants in the last two loci (BotF21 and BotF23) studied (Table S2).

Results from STRUCTURE and STRUCTURE HARVESTER indicated that three populations were represented among the 94 isolates (Fig 4). All populations consisted of a mix of isolates from both tree hosts, and from both sites sampled (Fig. 4), and isolates shared alleles at multiple loci (Table S2). These results were confirmed by the K-means output in GenoDive (Meirmans and Van Tienderen 2004) that indicated three populations, with the same isolates clustering together as in STRUCTURE, except that one isolate grouped with a different population. Additional STRUCTURE analyses on each subpopulation indicated no further substructure in the data. Low genotypic diversity $(0.383)$ was detected on the full dataset, although this did not differ significantly from what was expected $(P=0.159$, Table 2$)$. Genotypic diversity values for the $S$. birrea and $M$. indica populations differed slightly (not significant), with the $S$. birrea population more diverse than that from M. indica (Table 2). 
Following clone-correction, the dataset consisted of 78 isolates (27 from S. birrea and 51 from M. indica). For both the Index of Association and rBarD tests, values obtained for the population of $S$. birrea isolates fell within the range of expected values for those resulting from random datasets, indicating sexual outcrossing and linkage equilibrium amongst loci. However, the values obtained for the $M$. indica isolates, and for the combined dataset of isolates from both tree hosts, fell outside the range of expected values based on random datasets generated (Table 2). This indicated linkage disequilibrium amongst the loci of isolates of $M$. indica sampled. The AMOVA showed that most of the genetic variation was accounted for within the two populations ( $S$. birrea and $M$. indica), and not between them (Table 3).

Six alleles were unique to the $M$. indica population (Table 2). Gene diversity was slightly higher for M. indica than S. birrea. Moderate levels of genetic differentiation were detected between the $S$. birrea and $M$. indica populations $\left(F_{\mathrm{ST}}=0.065, G_{\mathrm{ST}}^{\prime}=0.136, D_{\mathrm{EST}}=0.076\right)$ (Wright 1978). For gene flow, the effective number of migrants inferred by Genepop was 0.522. Per population migration rates, as calculated by BIMr, indicated that there was more movement from M. indica to S. birrea populations (source: $S$. birrea $=0.875 \pm 0.006$, source: $M$. indica: $0.617 \pm 0.007$ ) than the other way round (source: $S$. birrea $=0.126 \pm$ 0.006, source: M. indica: $0.383 \pm 0.007$ ) (Table S3).

\section{Discussion}

At least 11 species of the Botryosphaeriaceae are associated with native Sclerocarya birrea trees in South Africa and all of these represent previously described taxa. Of these, Botryosphaeria fabicerciana, Lasiodiplodia iraniensis, and Neofusicoccum mediterraneum are recorded from South Africa for the first time. The remaining eight species (Diplodia allocellula, Lasiodiplodia crassispora, Lasiodiplodia gonubiensis, Lasiodiplodia mahajangana, Lasiodiplodia pseudotheobromae, Lasiodiplodia theobromae, Neofusicoccum parvum, Neofusicoccum umdonicola, Neofusicoccum vitifusiforme) have been isolated previously from other hosts in the country, including both native (Jami et al. 2012, 2014; Mehl et al. 2011; Pavlic et al. 2007) and non-native (Begoude et al. 2010; Damm et al. 2007; Mehl et al. 2014; Pavlic et al. 2007; van Niekerk et al. 2004) trees. This is, however, the first time that any of them have been recorded from $S$. birrea. 
Ten species of the Botryosphaeriaceae, including B. fabicerciana, L. mahajangana, L. pseudotheobromae, L. theobromae, Neofusicoccum australe, Neofusicoccum kwambonambiense, N. mediterraneum, N. parvum, N. umdonicola, and Pseudofusicoccum olivaceum, were isolated from Mangifera indica in this study. Of these, only L. theobromae, N. parvum, and Ps. olivaceum have previously been found on $M$. indica trees in South Africa (Trakunyingcharoen et al. 2014) while the remaining seven species represent first reports on this host in the country. Additionally, L. mahajangana, N. australe, N. kwambonambiense, and $N$. umdonicola add to the assemblage of Botryosphaeriaceae associated with M. indica globally (Trakunyingcharoen et al. 2014). Some of the species in the list compiled by Trakunyingcharoen et al. (2014) are known pathogens of $M$. indica and occur in South Africa, but were not recovered in this study. These include L. crassispora (van Niekerk et al. 2010) and Neofusicoccum mangiferae (Pavlic et al. 2007).

Several of the species isolated from $S$. birrea or $M$. indica trees in this study are known only from South Africa and might be native to the country. These species include $D$. allocellula, L. gonubiensis, and P. olivaceum, all of which previously occupied a limited distribution in the country. Diplodia allocellula was isolated from Acacia karroo trees in Pretoria, Gauteng Province (Jami et al. 2012), L. gonubiensis from Syzygium cordatum in Gonubie, Eastern Cape Province (Pavlic et al. 2007), and Ps. olivaceum from Pterocarpus angolensis and Terminalia sericea at several sites in the Mpumalanga Province (Mehl et al. 2011). Results of this study indicate that these fungi occupy broader distributions in the country and probably infect a greater number of hosts, both native and non-native.

A number of species isolated from either $S$. birrea and/or $M$. indica trees are possibly aliens in South Africa. Examples include B. fabicerciana that was first described in China from Eucalyptus species (Chen et al. 2011) and has been recorded from $M$. indica trees in Brazil (Marques et al. 2013), and L. theobromae that has been recovered from various native tree hosts and non-native fruit trees in South Africa (Jami et al. 2014). Apart from these, $L$. crassispora is possibly also alien as it was first described from Santalum album in Western Australia and Eucalyptus urophylla in Acarigua, Venezuela (Burgess et al. 2006a), and is also known to infect grapevine in California, USA (Úrbez-Torres et al. 2010). In South Africa, it has been isolated from Pt. angolensis in the Mpumalanga Province (Mehl 
et al. 2011) and grapevines in the Western Cape Province (van Niekerk et al. 2010) and likely infects other plant species in the country. These fungi illustrate an increasingly alarming pattern where many tree pathogens are being moved around the world unknowingly via infected plant tissue. They are consequently being introduced into novel areas where they can then infect a broad range of native and non-native hosts, potentially with negative consequences (Desprez-Loustau et al. 2007; Gladieux et al. 2015; Liebhold et al. 2012; Wingfield et al. 2015).

Neofusicoccum vitifusiforme was the dominant taxon amongst the 2006 isolations from S. birrea trees in the Kruger National Park (Mpumalanga Province) and Lakelands (Kwa-Zulu Natal Province) areas. This fungus has been associated in South Africa with various cultivated plants in the Western Cape and Gauteng Provinces, including grapevines (van Niekerk et al. 2004), plum and peach trees (Damm et al. 2007), and ornamental Schizolobium parahyba trees (Mehl et al. 2014). Its occurrence on S. birrea trees at all three sites sampled (located in the Limpopo, Mpumalanga and KwaZulu-Natal Provinces) suggests that it could either be native to South Africa or that it originated from other cultivated plants established in close proximity to $S$. birrea trees. It was not isolated in 2012, probably due to sampling having been restricted to Hoedspruit.

Neofusicoccum parvum was the dominant Botryosphaeriaceae species isolated from $S$. birrea and $M$. indica trees sampled in the Hoedspruit area in 2012, as well as from $M$. indica trees at the Hans Merensky estate in 2006. This was not unexpected as the fungus is a dominant Botryosphaeriaceae species on various woody hosts. These include almond trees in Spain (Gramaje et al. 2012), grapevines in Algeria and Uruguay (Abreo et al. 2013, Berraf-Tebbal et al. 2015), M. indica in Australia (Slippers et al. 2005), olives in Italy (Carlucci et al. 2013), Sch. parahyba in South Africa (Mehl et al. 2014), Terminalia catappa in South Africa (Begoude et al. 2010), and ornamental Tibouchina spp. in Australia, New Zealand and South Africa (Heath et al. 2011). More recently, the abundance of N. parvum in some areas has been linked to environmental disturbance and host composition linked to human activity (Pavlic-Zupanc et al. 2015). This could provide an explanation for the dominance of this pathogen from the samples obtained in this study.

Similar levels of genetic diversity were found within both the $S$. birrea and $M$. indica populations of $N$. parvum sampled in this study. The AMOVA on these data showed that 
the genetic variation observed was represented within the two populations, as opposed to diversity amongst the populations. Gene diversity was slightly higher in the $M$. indica population, possibly because more isolates were obtained from that host and because more $M$. indica trees were available to sample. Isolates obtained in this study had similar levels of genetic diversity as compared to previous studies considering this fungus in South Africa. Gene diversity $\left(H_{S}=0.519\right)$ was slightly lower than that reported by Sakalidis et al. $\left(2013, H_{S}=0.574\right)$, who considered isolates sampled from Eucalyptus sp., Syz. cordatum and $M$. indica trees, and Pavlic-Zupanc et al. (2015, $\left.H_{S}=0.579\right)$, who sampled from Syz. cordatum trees across the country. The high levels of gene diversity in all these studies adds weight to the suggestion (Sakalidis et al. 2013) that the fungus is native to South Africa, although the possibility that the fungus was introduced cannot be overruled.

Three populations of $N$. parvum were identified by STRUCTURE analysis, comprising isolates from both $S$. birrea and $M$. indica. A distinct population signifies a unique, ancestral lineage of the fungus (de Queiroz 1999). Each population comprised isolates from both tree hosts, indicating movement of the fungus between them. Other studies have also noted the presence of multiple lineages of $N$. parvum in South Africa. PavlicZupanc et al. (2015) identified three populations and Sakalidis et al. (2013) showed that South African isolates grouped within nine of the 12 lineages of this fungus. These lineages could represent additional cryptic species that are closely related. High levels of genetic variation and sub-clades within the species hinting at potential cryptic relatives have been noted in several studies (Abdollahzadeh et al. 2013; Baskarathevan et al. 2012; Chen et al. 2014). Three cryptic species have previously been identified by Pavlic et al. (2009) in South Africa and it is possible that the three lineages identified in this study also represent cryptic species. Analyses of multilocus sequence data would be required to confirm or refute this possibility.

Results from analyses of linkage disequilibrium on the combined population of $N$. parvum isolates from $S$. birrea and $M$. indica indicated that clonal reproduction is the dominant mode of reproduction. This is underscored by low genotypic diversity for both the complete dataset as well as for datasets from each host. Examination of allele frequencies also indicated that individual alleles dominated the profile at four of the six loci sampled (BotF11, BotF18, BotF21, and BotF23) in isolates from both hosts. While the sexual state of $N$. parvum has not been recorded in South Africa, the fungus probably reproduces both 
sexually and asexually, as alluded to by Sakalidis et al. (2013), and the high genetic diversity observed in this study may be due to unobserved outcrossing.

Low genetic differentiation and extensive gene flow characterized $N$. parvum isolates derived from the $S$. birrea and $M$. indica populations in this study. Similar results have been obtained in other studies on the Botryosphaeriaceae where neighbouring hosts have been sampled. Burgess et al. (2006b) sampled N. australe from native eucalypts and two adjacent plantations of non-native Eucalyptus globulus and showed that low differentiation and high gene flow were characteristic of these populations. Sakalidis et al. (2011) also demonstrated high levels of gene flow amongst populations of this fungus from native woody hosts. Likewise, Begoude et al. (2012) showed movement of both L. theobromae and L. pseudotheobromae between Terminalia species and Theobroma cacao. Cumulatively, results from all of these studies illustrate the ease with which the Botryosphaeriaceae can move between both native and non-native woody plants.

The global dissemination of plants by people (Bebber et al. 2014; Liebhold et al. 2012) has enabled the introduction and establishment of both $M$. indica and likely most of the Botryosphaeriaceae isolated in this study, into areas outside of their original geographic range. While several species of these fungi are possibly native, many have likely been unintentionally introduced, probably due to their endophytic persistence in infected, albeit asymptomatic, plant material (Slippers and Wingfield 2007). Most of the Botryosphaeriaceae isolated in this study are capable of infecting both S. birrea and $M$. indica simultaneously, including Botryosphaeria dothidea, L. crassispora, L. theobromae, N. mediterraneum, and N. parvum. Previous studies have noted the ability of these fungi to infect multiple tree species concurrently, including natives and non-natives (Begoude et al. 2012; Jami et al. 2014; Sakalidis et al. 2011). Added to this is the concern of introducing novel genotypes of a species already present in an area, which can become established and/or recombine with other genotypes already present to produce novel genotypes capable of infecting naïve hosts (Gladieux et al. 2015). The ability of these fungi to migrate among host plants can facilitate infections of novel hosts and threaten the sustainability of both commercially important plants as well as native ecosystems (Desprez-Loustau et al. 2007; Fisher et al. 2012).

\section{ACKNOWLEDGMENTS}


We thank the Department of Science and Technology (DST)-National Research Foundation (NRF) Centre of Excellence in Tree Health Biotechnology (CTHB) and members of the Tree Protection Co-operative Programme (TPCP), South Africa, for financial support. We are also grateful to the South African National Parks Board (SANPARKS) for issuing a permit to sample in the Kruger National Park. We also thank Mrs. Bianca Nel (née Hinze) and Ms. Sarah Briggs who initiated this project. Furthermore, Mr. Victor Kalbskopf and Ms. Elmien Slabbert assisted the lead author with some of the laboratory work required for this study and are thanked in this regard. Finally, we thank the editor and two anonymous reviewers whose comments helped improve this manuscript.

\section{REFERENCES}

Abdollahzadeh J, Zare R, Phillips AJL, 2013. Phylogeny and taxonomy of Botryosphaeria and Neofusicoccum species in Iran, with description of Botryosphaeria scharifii sp. nov. Mycologia 105: 210-220.

Abreo E, Martinez S, Bettucci L, Lupo S, 2013. Characterization of Botryosphaeriaceae species associated with grapevines in Uruguay. Australasian Plant Pathology 42: 241-249.

Agapow PM, Burt A, 2001. Indices of multilocus linkage disequilibrium. Molecular Ecology Notes 1: 101-102.

Barton NH, Slatkin M, 1986. A quasi-equilibrium theory of the distribution of rare alleles in a subdivided population. Heredity 56: 409-415.

Baskarathevan J, Jaspers MV, Jones EE, Cruickshank RH, Ridgway HJ, 2012. Genetic and pathogenic diversity of Neofusicoccum parvum in New Zealand vineyards. Fungal Biology 116: 276-288.

Bebber, D. P., Holmes, T., \& Gurr, S. J, 2014. The global spread of crop pests and pathogens. Global Ecology and Biogeography 23: 1398-1407.

Begoude BAD, Slippers B, Perez G, Wingfield MJ, Roux J, 2012. High gene flow and 
outcrossing within populations of two cryptic fungal pathogens on a native and non-native host in Cameroon. Fungal Biology 116: 343-353.

Begoude BAD, Slippers B, Wingfield MJ, Roux J, 2010. Botryosphaeriaceae associated with Terminalia catappa in Cameroon, South Africa and Madagascar. Mycological Progress 9: 101-123.

Berraf-Tebbal A, Guerreiro MA, Phillips AJL, 2015. Phylogeny of Neofusicoccum species associated with grapevine trunk disease in Algeria, with description of Neofusicoccum algeriense sp. nov. Phytopathologia Mediterranea 71: 201-214.

Burgess TI, Barber PA, Mohali S, Pegg G, de Beer ZW, Wingfield MJ, 2006a. Three new Lasiodiplodia spp. from the tropics, recognized based on DNA sequence comparisons and morphology. Mycologia 98: 423-435.

Burgess TI, Sakalidis ML, Hardy GESJ, 2006b. Gene flow of the canker pathogen Botryosphaeria australis between Eucalyptus globulus plantations and native eucalypt forests in Western Australia. Austral Ecology 31: 559-566.

Carbone I, Kohn LM, 1999. A method for designing primer sets for speciation studies in filamentous ascomycetes. Mycologia 91: 553-556.

Carlucci A, Raimondo ML, Cibelli F, Phillips AJL, Lops F, 2013. Pleurostomophora richardsiae, Neofusicoccum parvum and Phaeoacremonium aleophilum associated with a decline of olives in southern Italy. Phytopathologia Mediterranea 52: 517-527.

Chen S, Morgan DP, Hasey JK, Anderson K, Michailides TJ, 2014. Phylogeny, morphology, distribution, and pathogenicity of Botryosphaeriaceae and Diaporthaceae from English walnut in California. Plant Disease 98: 636-652.

Chen S, Pavlic D, Roux J, Slippers B, Xie Y, Wingfield MJ, Zhou X, 2011. Characterization of Botryosphaeriaceae from plantation-grown Eucalyptus species in South China. Plant Pathology 60: 739-751. 
Crous PW, Phillips AJL, Baxter AP, 2000. Phytopathogenic fungi from South Africa. University of Stellenbosch, Department of Plant Pathology Press.

Damm U, Crous PW, Fourie PH, 2007. Botryosphaeriaceae as potential pathogens of Prunus species in South Africa, with descriptions of Diplodia africana and Lasiodiplodia plurivora sp. nov. Mycologia 99: 664-680.

Darrida D, Taboada GL, Doallo R, Posada D, 2012. jModelTest 2: more models, new heuristics and parallel computing. Nature Methods 9: 772.

de Queiroz K, 1999. The general lineage concept of species and the defining properties of the species category. In: Wilson R (ed), Species: new interdisciplinary essays. MIT Press, London, pp. 49-89.

Desprez-Loustau M-L, Robin C, Buée M, Courtecuisse R, Garbaye J, Suffert F, Sache I, Rizzo DM, 2007. The fungal dimension of biological invasions. Trends in Ecology and Evolution 22: 472-480.

Doidge EM, 1950. The South African fungi and lichens to the end of 1945. Bothalia 5: 11094.

Earl DA, vonHoldt BM, 2012. STRUCTURE HARVESTER: a website and program for visualizing STRUCTURE output and implementing the Evanno method, Conservation Genetics Resources 4: 359-361.

Evanno G, Regnaut S, Goudet J, 2005. Detecting the number of clusters of individuals using the software STRUCTURE: a simulation study. Molecular Ecology 14: 2611-2620.

Excoffier L, Smouse PE, Quattro JM, 1992. Analysis of molecular variance inferred from metric distances among DNA haplotypes: application to human mitochondrial DNA restriction data. Genetics 131: 479-491.

Farr DF, Rossman AY, 2016. Fungal Databases, Systematic Mycology and Microbiology Laboratory, ARS, USDA. From http://nt.ars-grin.gov/fungaldatabases/ (retrieved 
16/3/2016).

Faubet $P$, Gaggiotti OE, 2008. A new Bayesian method to identify the environmental factors that influence recent migration. Genetics 178: 1491-1504.

Fisher MC, Henk DA, Briggs CJ, Brownstein JS, Madoff LC, McCraw SL, Gurr SJ, 2012. Emerging fungal threats to animal, plant and ecosystem health. Nature 484: 186-194.

Gladieux P, Feurtey A, Hood ME, Snirc A, Clavel J, Dutech C, Roy M, Giraud T, 2015. The population biology of fungal invasions. Molecular Ecology 24: 1969-1986.

Glass NL, Donaldson, GC, 1995. Development of primer sets designed for use with the PCR to amplify conserved genes from filamentous ascomycetes. Applied and Environmental Microbiology 61: 1323-1330.

Gramaje D, Agusti-Brisach C, Perez-Sierra A, Moralejo E, Olmo D, Mostert L, Damm U, Armengol J, 2012. Fungal trunk pathogens associated with wood decay of almond trees on Mallorca (Spain). Persoonia 28: 1-13.

Guindon S, Dufayard J-F, Lefort V, Anisimova M, Hordijk W, Gascuel O, 2010. New algorithms and methods to estimate maximum-likelihood phylogenies: assessing the performance of PhyML 3.0. Systematic Biology 59: 307-321.

Halkett F, Simon JC, Balloux F, 2005. Tackling the population genetics of clonal and partially clonal organisms. Trends in Ecology \& Evolution 20: 194-201.

Heath RN, Roux J, Slippers B, Drenth A, Pennycook SR, Wingfield BD, Wingfield MJ, 2011. Occurrence and pathogenicity of Neofusicoccum parvum and N. mangiferae on ornamental Tibouchina species. Forest Pathology 41: 48-51.

Hubisz MJ, Falush D, Stephens M, Pritchard JK, 2009. Inferring weak population structure with the assistance of sample group information. Molecular Ecology Resources 9: 13221332. 
Jacobs K, Bergdahl DR, Wingfield MJ, Halik S, Seifert KA, Bright DE, Wingfield BD, 2004. Leptographium wingfieldii introduced into North America and found associated with exotic Tomicus piniperda and native bark beetles. Mycological Research 108: 411-418.

Jami F, Slippers B, Wingfield MJ, Gryzenhout M, 2014. Botryosphaeriaceae species overlap on four unrelated, native South African hosts. Fungal Biology 118: 168-179.

Jami F, Slippers B, Wingfield MJ, Gryzenhout M, 2012. Five new species of the Botryosphaeriaceae from Acacia karroo in South Africa. Cryptogamie Mycologie 33: 245266.

Johnson GI, Kotze JM, 1994. Stem-end rot. In: Ploetz RC, Zentmyer GA, Nishijima WT, Rohrbach KG, Ohr HD (eds), Compendium of tropical fruit diseases, 1st edn. APS Press, St. Paul, Minnesota, pp. 81-83.

Katoh K, Toh H, 2008. Recent developments in the MAFFT multiple sequence alignment program. Briefings in Bioinformatics 9: 286-298.

Liebhold AM, Brockerhoff EG, Garrett LJ, Parke JL, Britton KO, 2012. Live plant imports: the major pathway for forest insect and pathogen invasions of the US. Frontiers in Ecology and the Environment 10: 135-143.

Marques MW, Lima NB, de Morais Jr. MA, Michereff SJ, Phillips AJL Câmara MP, 2013. Botryosphaeria, Neofusicoccum, Neoscytalidium and Pseudofusicoccum species associated with mango in Brazil. Fungal Diversity 61: 195-208.

Mehl JWM, Slippers B, Roux J, Wingfield MJ, 2011. Botryosphaeriaceae associated with Pterocarpus angolensis (kiaat) in South Africa. Mycologia 103: 534-553.

Mehl JWM, Slippers B, Roux J, Wingfield MJ, 2013. Cankers and other diseases caused by the Botryosphaeriaceae. In: Gonthier P, Nicolotti G (eds), Infectious Forest Diseases. CAB International, Oxon, UK, pp. 298-317.

Mehl JWM, Slippers B, Roux J, Wingfield MJ, 2014. Botryosphaeriaceae associated with 
die-back of Schizolobium parahyba trees in South Africa and Ecuador. Forest Pathology 44: 396-408.

Meirmans PG, Van Tienderen PH, 2004. GENOTYPE and GENODIVE: two programs for the analysis of genetic diversity of asexual organisms. Molecular Ecology Notes 4: 792794.

Menge JA, Ploetz RC, 2003. Diseases of avocado. In: Ploetz RC (ed), Diseases of tropical fruit crops. CAB International, Oxon, UK, pp. 35-71.

Pavlic D, Slippers B, Coutinho TA, Gryzenhout M, Wingfield MJ, 2004. Lasiodiplodia gonubiensis sp. nov., a new Botryosphaeria anamorph from native Syzygium cordatum in South Africa. Studies in Mycology 50: 313-322.

Pavlic D, Slippers B, Coutinho TA, Wingfield MJ, 2007. Botryosphaeriaceae occurring on native Syzygium cordatum in South Africa and their potential threat to Eucalyptus. Plant Pathology 56: 624-636.

Pavlic D, Slippers B, Coutinho TA, Wingfield MJ, 2009. Molecular and phenotypic characterisation of three phylogenetic species discovered within the Neofusicoccum parvum/N. ribis complex. Mycologia 101: 636-647.

Pavlic-Zupanc D, Wingfield MJ, Boissin E, Slippers B, 2015. The distribution of genetic diversity in the Neofusicoccum parvum/N. ribis complex suggests structure correlated with level of disturbance. Fungal Ecology 13: 93-102.

Peters CR, 1988. Notes on the distribution and relative abundance of Sclerocarya birrea (A. Rich.) Hochst. (Anacardiaceae). Monographs in Systematic Botany from the Missouri Botanical Garden 25: 403-410.

Phillips AJL, Alves A, 2009. Taxonomy, phylogeny, and epitypification of Melanops tulasnei, the type species of Melanops. Fungal Diversity 38: 155-166.

Ploetz RC, 2003. Diseases of mango. In: Ploetz RC (ed), Diseases of tropical fruit crops. 
CAB International, Oxon, UK, pp. 327-363.

Rousset F, 2008. Genepop'007: a complete reimplementation of the Genepop software for Windows and Linux. Molecular Ecology Resources 8: 103-106.

Sakalidis ML, Hardy GESJ, Burgess TI, 2011. Class III endophytes, clandestine movement amongst hosts and habitats and their potential for disease; a focus on Neofusicoccum australe. Australasian Plant Pathology 40: 510-521.

Sakalidis ML, Slippers B, Wingfield BD, Hardy GESJ, Burgess TI, 2013. The challenge of understanding the origin, pathways and extent of fungal invasions: global populations of the Neofusicoccum parvum-N. ribis species complex. Diversity and Distributions 19: 873883.

Shackleton SE, Shackleton CM, Cunningham T, Lombard C, Sullivan CA, Netshiluvhi TR, 2002. Knowledge on Sclerocarya birrea subsp. caffra with emphasis on its importance as a non-timber forest product in South and southern Africa: A summary. Part 1: Taxonomy, ecology and role in rural livelihoods. Southern African Forestry Journal 194: 27-41.

Slippers B, Burgess TI, Pavlic D, Ahumada R, Maleme H, Mohali S, Rodas CA, Wingfield MJ, 2009. A diverse assemblage of Botryosphaeriaceae infect Eucalyptus in native and non-native environments. Southern Forests 71: 101-110.

Slippers B, Burgess TI, Wingfield BD, Crous PW, Coutinho TA, Wingfield MJ, 2004. Development of simple sequence repeat markers for Botryosphaeria spp. with Fusicoccum anamorphs. Molecular Ecology Notes 4: 675-677.

Slippers B, Johnson GI, Crous PW, Coutinho TA, Wingfield BD, Wingfield MJ, 2005. Phylogenetic and morphological re-evaluation of the Botryosphaeria species causing diseases of Mangifera indica. Mycologia 97: 99-110.

Slippers B, Wingfield MJ, 2007. Botryosphaeriaceae as endophytes and latent pathogens of woody plants: diversity, ecology and impact. Fungal Biology Reviews 21: 90-106. 
Smith H, Wingfield MJ, Crous PW, Coutinho TA, 1996. Sphaeropsis sapinea and Botryosphaeria dothidea endophytic in Pinus spp. and Eucalyptus spp. in South Africa. South African Journal of Botany 62: 86-88.

Snyman JC, 1998. Origin and history of the mango. In: de Villiers EA (ed), The cultivation of mangoes. Institute for Tropical and Subtropical Crops, Agricultural Research Council, Nelspruit, pp. 1-3.

Stanosz GR, Smith DR, Leisso R, 2007. Diplodia shoot blight and asymptomatic persistence of Diplodia pinea on or in stems of jack pine nursery seedlings. Forest Pathology 37: 145-154.

Stöver BC, Müller KF, 2010. TreeGraph 2: Combining and visualizing evidence from different phylogenetic analyses. BMC Bioinformatics 11: 7.

Swart WJ, Wingfield MJ, Knox-Davies PS, 1987. Conidial dispersal of Sphaeropsis sapinea in three climatic regions of South Africa. Plant Disease 71: 1038-1040.

Swofford DL, 2003. PAUP*. Phylogenetic Analysis Using Parsimony ( ${ }^{*}$ and Other Methods), version 4. Sinauer Associates, Sunderland, MA.

Tamura K, Peterson D, Peterson N, Stecher G, Nei M, Kumar S, 2011. MEGA5: molecular evolutionary genetics analysis using maximum likelihood, evolutionary distance, and maximum parsimony methods. Molecular Biology and Evolution 28: 2731-2739.

Trakunyingcharoen T, Cheewangkoon R, To-anun C, Crous PW, van Niekerk JM, Lombard L, 2014. Botryosphaeriaceae associated with diseases of mango (Mangifera indica). Australasian Plant Pathology 43: 425-438.

Úrbez-Torres JR, Peduto F, Gubler WD, 2010. First report of grapevine cankers caused by Lasiodiplodia crassispora and Neofusicoccum mediterraneum in California. Plant Disease 94: 785 .

van Niekerk JM, Bester W, Halleen F, Crous PW, Fourie PH, 2010. First report of 
Lasiodiplodia crassispora as a pathogen of grapevine trunks in South Africa. Plant Disease 94: 1063.

van Niekerk JM, Crous PW, Groenewald JE, Fourie PH, Halleen F, 2004. DNA phylogeny, morphology and pathogenicity of Botryosphaeria species on grapevines. Mycologia 96: 781-798.

van Wyk M, van der Merwe NA, Roux J, Wingfield BD, Kamgan GN, Wingfield MJ, 2006. Population genetic analyses suggest that the Eucalyptus fungal pathogen Ceratocystis fimbriata has been introduced into South Africa. South African Journal of Science 102: 259-263.

White TJ, Bruns T, Lee S, Taylor J, 1990. Amplification and direct sequencing of fungal ribosomal RNA genes for phylogenetics. In: Innis MA, Gelfand DH, Sninsky JJ, White TJ (eds), PCR protocols: a guide to methods and applications. Academic Press, San Diego, pp. 315-322.

Wingfield MJ, Brockerhoff EG, Wingfield BD, Slippers B, 2015. Planted forest health: The need for a global strategy. Science 349: 832-836.

Wright LP, Davis AJ, Wingfield BD, Crous PW, Brenneman T, Wingfield MJ, 2010. Population structure of Cylindrocladium parasiticum infecting peanuts (Arachis hypogaea) in Georgia, USA. European Journal of Plant Pathology 127: 199-206.

Wright S, 1978. Evolution and the genetics of populations: A treatise in four volumes: Vol. 4: Variability within and among natural populations. University of Chicago Press, Chicago. 
Table S1 - Summary of species collected and counts of associated isolates per site.

Table S2 - Allele sizes (bp) and frequencies at six loci in the N. parvum isolates collected in this study, after clone-correction. Frequencies are given for the subsets of isolates from each host collected (S. birrea and $M$. indica) as well as for the total combined dataset.

Table S3 - Per population migration rates as calculated by BIMr. Included are migration rates for N. parvum from S. birrea onto either host and from $M$. indica onto either host, with associated standard errors.

Fig 1 - Map representing sites sampled (indicated by stars). A-F designate either one of both tree hosts sampled at a site, and are represented by pie charts that show species sampled at a site as well as the proportion of isolates obtained for that species. Map sources: https://en.wikipedia.org/wiki/File:Map_of_South_Africa_with_English_labels.svg, http://www.d-maps.com/carte.php?num_car=23733\&lang=en

Fig 2 - Maximum likelihood (ML) tree resulting from analysis on the combined dataset of ITS and tef1 sequence data for the first group. The tree is rooted to two isolates of Melanops tulasnei (CBS 116805, CBS 116806). Bootstrap values above $70 \%$ for the ML analysis (normal) and maximum parsimony analysis (italicized) appear at the relevant nodes. A bold $T$ after an isolate designates an ex-type isolate for the respective species. Isolates in bold were obtained during this study. Species obtained from either $S$. birrea (green) or M. indica (yellow) are designated with circles before the species name. 
Fig 3 - Unrooted maximum likelihood trees resulting from analysis of the ITS (A), tef1 (B), tub2 (C) and combined (D) sequence datasets for isolates grouping with known species within the N. parvum-ribis species complex. Bootstrap values above $70 \%$ for the $\mathrm{ML}$ analysis (normal) and maximum parsimony analysis (italicized) appear at the relevant nodes. A bold $\mathrm{T}$ after an isolate designates an ex-type isolate for the respective species while a bold $\mathrm{P}$ designates a paratype isolate. Isolates in bold were obtained during this study. Species obtained from either S. birrea (green) or M. indica (yellow) are designated with circles above the species name.

Fig 4 - Results of the STRUCTURE analyses done for Neofusicoccum parvum isolates. The optimal number of populations present (3) is signalled by the highest DeltaK peak. The corresponding barplot shows individual isolates, grouped according to population assigned, in order of $Q$, with populations assigned colours of red, green and blue. Circles beneath designate isolates from S. birrea (green) or M. indica (yellow).

Fig S1 - Maximum likelihood (ML) tree resulting from analysis on the ITS dataset for the first group. The tree is rooted to two isolates of Melanops tulasnei (CBS116805, CBS116806). Bootstrap values above $70 \%$ for the ML analysis (normal) and maximum parsimony analysis (italicized) appear at the relevant nodes. A bold T after an isolate designates an ex-type isolate for the respective species. Isolates in bold were obtained during this study. Species obtained from either S. birrea (green) or M. indica (yellow) are designated with circles before the species name.

Fig S2 - Maximum likelihood (ML) tree resulting from analysis on the tef1 dataset for the first group. The tree is rooted to two isolates of Melanops tulasnei (CBS116805, CBS116806). Bootstrap values above $70 \%$ for the ML analysis (normal) and maximum parsimony analysis (italicized) appear at the relevant nodes. A bold T after an isolate designates an ex-type isolate for the respective species. Isolates in bold were obtained during this study. Species obtained from either S. birrea (green) or M. indica (yellow) are designated with circles before the species name. 
Table 1

\begin{tabular}{|c|c|c|c|c|c|c|c|c|}
\hline Species & $\begin{array}{l}\text { Culture } \\
\text { number }\end{array}$ & $\begin{array}{l}\text { Other } \\
\text { numbers }\end{array}$ & Host & Location & Collector(s) & ITS & tef1 & tub2 \\
\hline $\begin{array}{l}\text { Botryosphaeria } \\
\text { fabicerciana }\end{array}$ & CMW 27094 & $\begin{array}{l}\text { CBS } \\
127193\end{array}$ & $\begin{array}{l}\text { Eucalyptus } \\
\text { sp. }\end{array}$ & $\begin{array}{l}\text { FuJian Province, } \\
\text { China }\end{array}$ & M. J. Wingfield & HQ332197 & HQ332213 & \\
\hline B. fabicerciana & CMW 27121 & $\begin{array}{l}\text { CBS } \\
127194\end{array}$ & $\begin{array}{l}\text { E. grandis } \\
\text { hybrid }\end{array}$ & $\begin{array}{l}\text { FuJian Province, } \\
\text { China }\end{array}$ & M. J. Wingfield & HQ332198 & HQ332214 & \\
\hline B. fabicerciana & CMW 25215 & & $\begin{array}{l}\text { Mangifera } \\
\text { indica }\end{array}$ & $\begin{array}{l}\text { Hans Merensky } \\
\text { Estate, Limpopo } \\
\text { Province, S. Africa }\end{array}$ & B. Hinze & KU997394 & KU997130 & KU997568 \\
\hline B. fabicerciana & & MAN2132 & M. indica & $\begin{array}{l}\text { Hoedspruit- } \\
\text { Klaserie Road, } \\
\text { Limpopo Province, } \\
\text { S. Africa }\end{array}$ & J. Roux & KU997460 & KU997237 & KU997579 \\
\hline B. fabicerciana & & MAN25238 & M. indica & $\begin{array}{l}\text { Hoedspruit- } \\
\text { Klaserie Road, } \\
\text { Limpopo Province, } \\
\text { S. Africa }\end{array}$ & J. Roux & KU997558 & KU997319 & \\
\hline B. fabicerciana & & MAR28238 & $\begin{array}{l}\text { Sclerocarya } \\
\text { birrea } \\
\text { subsp. } \\
\text { caffra }\end{array}$ & $\begin{array}{l}\text { Hoedspruit- } \\
\text { Klaserie Road, } \\
\text { Limpopo Province, } \\
\text { S. Africa }\end{array}$ & J. Roux & KU997549 & KU997310 & KU997616 \\
\hline
\end{tabular}




\begin{tabular}{|c|c|c|c|c|c|c|c|}
\hline Diplodia allocellula & CMW 36468 & $\begin{array}{l}\text { CBS } \\
130408\end{array}$ & $\begin{array}{l}\text { Acacia } \\
\text { karroo }\end{array}$ & Pretoria, S. Africa & $\begin{array}{l}\text { F. Jami \& M. } \\
\text { Gryzenhout }\end{array}$ & JQ239397 & JQ239384 \\
\hline D. allocellula & CMW 36469 & $\begin{array}{l}\text { CBS } \\
130409\end{array}$ & Ac. karroo & Pretoria, S. Africa & $\begin{array}{l}\text { F. Jami \& M. } \\
\text { Gryzenhout }\end{array}$ & JQ239398 & JQ239385 \\
\hline D. allocellula & CMW 24131 & & $\begin{array}{l}\text { S. birrea } \\
\text { subsp. } \\
\text { caffra }\end{array}$ & $\begin{array}{l}\text { Zululand, } \\
\text { KwaZulu-Natal, S. } \\
\text { Africa }\end{array}$ & B. Hinze & KU997376 & KU997114 \\
\hline $\begin{array}{l}\text { Lasiodiplodia } \\
\text { crassispora }\end{array}$ & CMW 13488 & & $\begin{array}{l}\text { Eucalyptus } \\
\text { urophylla }\end{array}$ & Venezuela & S. Mohali & $D Q 103552$ & $D Q 103559$ \\
\hline L. crassispora & CMW 14688 & WAC12534 & $\begin{array}{l}\text { Santalum } \\
\text { album }\end{array}$ & $\begin{array}{l}\text { Ord River, } \\
\text { Kununurra, W.A. }\end{array}$ & T. Burgess & $D Q 103551$ & $D Q 103558$ \\
\hline L. crassispora & CMW 14691 & WAC12533 & San. album & $\begin{array}{l}\text { Ord River, } \\
\text { Kununurra, W.A. }\end{array}$ & T. Burgess & $D Q 103550$ & $D Q 103557$ \\
\hline L. crassispora & CMW 24111 & & $\begin{array}{l}\text { S. birrea } \\
\text { subsp. } \\
\text { caffra }\end{array}$ & $\begin{array}{l}\text { Zululand, } \\
\text { KwaZulu-Natal, S. } \\
\text { Africa }\end{array}$ & B. Hinze & KU997362 & KU997103 \\
\hline L. gonubiensis & CMW 14077 & CBS 115812 & $\begin{array}{l}\text { Syzygium } \\
\text { cordatum }\end{array}$ & $\begin{array}{l}\text { Gonubie, Eastern } \\
\text { Cape, S. Africa }\end{array}$ & D. Pavlic & AY639595 & $D Q 103566$ \\
\hline L. gonubiensis & CMW 14078 & CBS 116355 & $\begin{array}{l}\text { Syz. } \\
\text { cordatum }\end{array}$ & $\begin{array}{l}\text { Gonubie, Eastern } \\
\text { Cape, }\end{array}$ & D. Pavlic & AY639594 & $D Q 103567$ \\
\hline L. gonubiensis & CMW 24123 & & $\begin{array}{l}\text { S. birrea } \\
\text { subsp. } \\
\text { caffra }\end{array}$ & $\begin{array}{l}\text { Zululand, } \\
\text { KwaZulu-Natal, S. } \\
\text { Africa }\end{array}$ & B. Hinze & KU997370 & KU997109 \\
\hline L. gonubiensis & CMW 24127 & & S. birrea & Zululand, & B. Hinze & KU997374 & KU997113 \\
\hline
\end{tabular}




\begin{tabular}{|c|c|c|c|c|c|c|c|c|}
\hline & & & $\begin{array}{l}\text { subsp. } \\
\text { caffra }\end{array}$ & $\begin{array}{l}\text { KwaZulu-Natal, S. } \\
\text { Africa }\end{array}$ & & & & \\
\hline L. iraniensis & CBS 124710 & IRAN1520C & $\begin{array}{l}\text { Salvadora } \\
\text { persica }\end{array}$ & Hormozgan, Iran & $\begin{array}{l}\text { J. } \\
\text { Abdollahzadeh } \\
\text { /A. Javadi }\end{array}$ & GU945348 & GU945336 & \\
\hline L. iraniensis & CBS 124711 & IRAN1502C & Juglans sp. & Golestan, Iran & A. Javadi & GU945347 & GU945335 & \\
\hline L. iraniensis & CMW 25232 & & $\begin{array}{l}\text { S. birrea } \\
\text { subsp. } \\
\text { caffra }\end{array}$ & $\begin{array}{l}\text { Zululand, } \\
\text { KwaZulu-Natal, S. } \\
\text { Africa }\end{array}$ & B. Hinze & KU997384 & KU997119 & \\
\hline L. mahajangana & CMW 27801 & $\begin{array}{l}\text { CBS } \\
124925\end{array}$ & $\begin{array}{l}\text { Terminalia } \\
\text { catappa }\end{array}$ & $\begin{array}{l}\text { Mahajanga, } \\
\text { Madagascar }\end{array}$ & J. Roux & FJ900595 & FJ900641 & \\
\hline L. mahajangana & CMW 27818 & $\begin{array}{l}\text { CBS } \\
124926\end{array}$ & Ter. catappa & $\begin{array}{l}\text { Mahajanga, } \\
\text { Madagascar }\end{array}$ & J. Roux & FJ900596 & FJ900642 & \\
\hline L. mahajangana & CMW 27820 & $\begin{array}{l}\text { CBS } \\
124927\end{array}$ & Ter. catappa & $\begin{array}{l}\text { Mahajanga, } \\
\text { Madagascar }\end{array}$ & J. Roux & FJ900597 & FJ900643 & \\
\hline L. mahajangana & CMW 25199 & & M. indica & $\begin{array}{l}\text { Hans Merensky } \\
\text { Estate, Limpopo } \\
\text { Province, S. Africa }\end{array}$ & B. Hinze & KU997387 & KU997121 & KU997563 \\
\hline L. mahajangana & CMW 25202 & & M. indica & $\begin{array}{l}\text { Hans Merensky } \\
\text { Estate, Limpopo } \\
\text { Province, S. Africa }\end{array}$ & B. Hinze & KU997388 & KU997122 & KU997564 \\
\hline L. mahajangana & & MAR1212 & $\begin{array}{l}\text { S. birrea } \\
\text { subsp. }\end{array}$ & $\begin{array}{l}\text { Hoedspruit- } \\
\text { Klaserie Road, }\end{array}$ & J. Roux & KU997455 & KU997231 & \\
\hline
\end{tabular}




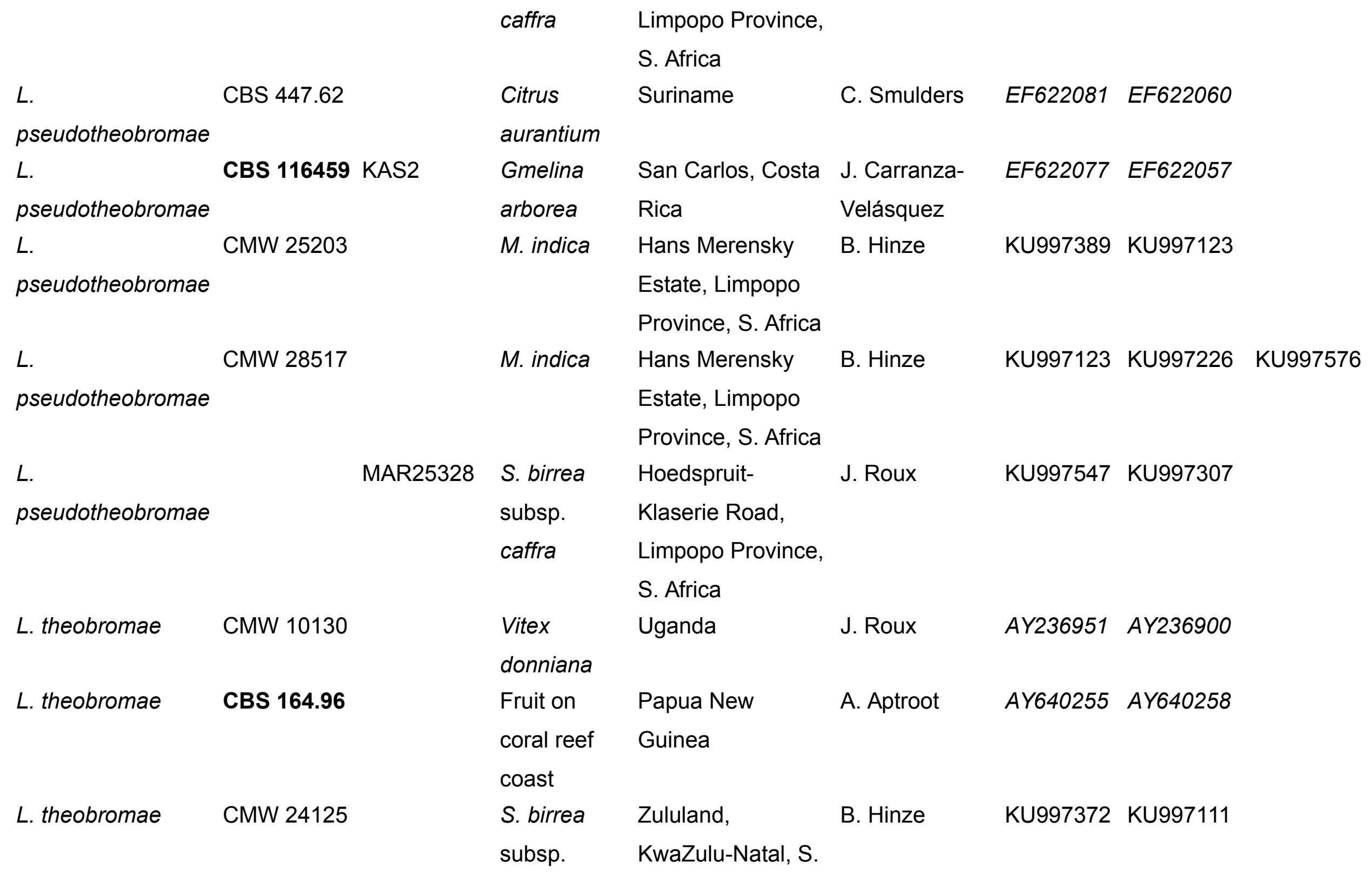




\begin{tabular}{|c|c|c|c|c|c|c|c|c|}
\hline & & & caffra & Africa & & & & \\
\hline L. theobromae & CMW 25212 & & M. indica & $\begin{array}{l}\text { Hans Merensky } \\
\text { Estate, Limpopo } \\
\text { Province, S. Africa }\end{array}$ & B. Hinze & KU997392 & KU997128 & KU997566 \\
\hline Melanops tulasnei & CBS 116805 & & $\begin{array}{l}\text { Quercus } \\
\text { robur }\end{array}$ & $\begin{array}{l}\text { Bavaria, Munich, } \\
\text { Germany }\end{array}$ & P. A. Saccardo & FJ824769 & FJ824774 & \\
\hline M. tulasnei & CBS 116806 & & Q. robur & $\begin{array}{l}\text { Bavaria, Munich, } \\
\text { Germany }\end{array}$ & P. A. Saccardo & FJ824770 & FJ824775 & \\
\hline $\begin{array}{l}\text { Neofusicoccum } \\
\text { australe }\end{array}$ & CBS 112872 & STE-U4425 & Vitis vinifera & $\begin{array}{l}\text { Stellenbosch, } \\
\text { Western Cape, S. } \\
\text { Africa }\end{array}$ & F. Halleen & AY343388 & AY343347 & \\
\hline N. australe & CBS 112877 & STE-U4415 & V. vinifera & $\begin{array}{l}\text { Stellenbosch, } \\
\text { Western Cape, S. } \\
\text { Africa }\end{array}$ & F. Halleen & AY343385 & AY343346 & \\
\hline N. australe & CMW 25211 & & M. indica & $\begin{array}{l}\text { Hans Merensky } \\
\text { Estate, Limpopo } \\
\text { Province, S. Africa }\end{array}$ & B. Hinze & KU997391 & KU997127 & \\
\hline $\begin{array}{l}\text { N. } \\
\text { kwambonambiense }\end{array}$ & CMW 14023 & $\begin{array}{l}\text { CBS } \\
123639\end{array}$ & $\begin{array}{l}\text { Syzygium } \\
\text { cordatum }\end{array}$ & $\begin{array}{l}\text { Kwambonambi, S. } \\
\text { Africa }\end{array}$ & D. Pavlic & EU821900 & EU821870 & EU821840 \\
\hline $\begin{array}{l}\text { N. } \\
\text { kwambonambiense }\end{array}$ & CMW 14123 & $\begin{array}{l}\text { CBS } \\
123643\end{array}$ & $\begin{array}{l}\text { Syz. } \\
\text { cordatum }\end{array}$ & $\begin{array}{l}\text { Kwambonambi, S. } \\
\text { Africa }\end{array}$ & D. Pavlic & EU821924 & EU821894 & EU821864 \\
\hline $\begin{array}{l}\text { N. } \\
\text { kwambonambiense }\end{array}$ & CMW 25198 & & M. indica & $\begin{array}{l}\text { Hans Merensky } \\
\text { Estate, Limpopo }\end{array}$ & B. Hinze & KU997386 & KU997120 & KU997562 \\
\hline
\end{tabular}




\begin{tabular}{|c|c|c|c|c|c|c|c|c|}
\hline & & & & Province, S. Africa & & & & \\
\hline$N$ & CMW 28412 & & M. indica & Hans Merensky & B. Hinze & KU997418 & KU997143 & KU997572 \\
\hline kwambonambiense & & & & Estate, Limpopo & & & & \\
\hline & & & & Province, S. Africa & & & & \\
\hline$N$ & & MAN210316 & M. indica & Hoedspruit- & J. Roux & KU997532 & KU997290 & KU997605 \\
\hline kwambonambiense & & & & Klaserie Road, & & & & \\
\hline & & & & Limpopo Province, & & & & \\
\hline & & & & S. Africa & & & & \\
\hline N. mediterraneum & CBS 121558 & PD311 & Olea & Lepre, Scorrano, & C. Lazzizera & GU799463 & GU799462 & \\
\hline & & & europaea & Italy & & & & \\
\hline N. mediterraneum & CBS 121718 & CPC13137, & Eucalyptus & Rhodes, Greece & P. Crous, M. J. & GU251176 & GU251308 & \\
\hline & & PD312 & sp. & & Wingfield, A. & & & \\
\hline & & & & & Phillips & & & \\
\hline N. mediterraneum & CMW 24080 & & S. birrea & Kruger National & B. Hinze & KU997339 & KU997094 & \\
\hline & & & subsp. & Park, Mpumalanga & & & & \\
\hline & & & caffra & Province, S. Africa & & & & \\
\hline N. mediterraneum & CMW 24083 & & S. birrea & Kruger National & B. Hinze & KU997341 & KU997095 & \\
\hline & & & subsp. & Park, Mpumalanga & & & & \\
\hline & & & caffra & Province, S. Africa & & & & \\
\hline N. mediterraneum & CMW 24122 & & S. birrea & Zululand, & B. Hinze & KU997369 & KU997108 & \\
\hline & & & subsp. & KwaZulu-Natal, S. & & & & \\
\hline & & & caffra & Africa & & & & \\
\hline N. mediterraneum & MAN21312 & & M. indica & Hoedspruit- & J. Roux & KU997470 & KU997247 & KU997588 \\
\hline
\end{tabular}


Klaserie Road,

Limpopo Province,

\section{S. Africa}

\begin{tabular}{|c|c|c|c|c|c|c|c|c|}
\hline N. parvum & CMW 9081 & $\begin{array}{l}\text { ICMP8003, } \\
\text { ATCC58191 }\end{array}$ & $\begin{array}{l}\text { Populus } \\
\text { nigra }\end{array}$ & $\begin{array}{l}\text { TePuke/BP, New } \\
\text { Zealand }\end{array}$ & G. Samuels & AY236943 & AY236888 & AY236917 \\
\hline N. parvum & CBS 110301 & CAP074 & V. vinifera & Palmella, Portugal & A. Phillips & AY259098 & AY573221 & EU673095 \\
\hline N. parvum & CMW 28377 & & M. indica & $\begin{array}{l}\text { Hans Merensky } \\
\text { Estate, Limpopo } \\
\text { Province, S. Africa }\end{array}$ & B. Hinze & KU997395 & KU997131 & KU997569 \\
\hline N. parvum & & MAR11328 & $\begin{array}{l}\text { S. birrea } \\
\text { subsp. } \\
\text { caffra }\end{array}$ & $\begin{array}{l}\text { Hoedspruit- } \\
\text { Klaserie Road, } \\
\text { Limpopo Province, } \\
\text { S. Africa }\end{array}$ & J. Roux & KU997539 & KU997293 & KU997607 \\
\hline N. parvum & & MAR21022 & $\begin{array}{l}\text { S. birrea } \\
\text { subsp. } \\
\text { caffra }\end{array}$ & $\begin{array}{l}\text { Hoedspruit- } \\
\text { Klaserie Road, } \\
\text { Limpopo Province, } \\
\text { S. Africa }\end{array}$ & J. Roux & KU997456 & KU997232 & KU997577 \\
\hline N. parvum & & MAR2134 & $\begin{array}{l}\text { S. birrea } \\
\text { subsp. } \\
\text { caffra }\end{array}$ & $\begin{array}{l}\text { Hoedspruit- } \\
\text { Klaserie Road, } \\
\text { Limpopo Province, } \\
\text { S. Africa }\end{array}$ & J. Roux & KU997474 & KU997252 & KU997593 \\
\hline N. umdonicola & CMW 14058 & $\begin{array}{l}\text { CBS } \\
123645\end{array}$ & $\begin{array}{l}\text { Syz. } \\
\text { cordatum }\end{array}$ & Kosi Bay, S. Africa & D. Pavlic & EU821904 & EU821874 & EU821844 \\
\hline
\end{tabular}




\begin{tabular}{|c|c|c|c|c|c|c|c|c|}
\hline N. umdonicola & CMW 14106 & $\begin{array}{l}\text { CBS } \\
123644\end{array}$ & $\begin{array}{l}\text { Syz. } \\
\text { cordatum }\end{array}$ & $\begin{array}{l}\text { Sodwana Bay, S. } \\
\text { Africa }\end{array}$ & D. Pavlic & EU821905 & EU821875 & EU821839 \\
\hline N. umdonicola & & MAN210236 & M. indica & $\begin{array}{l}\text { Hoedspruit- } \\
\text { Klaserie Road, } \\
\text { Limpopo Province, } \\
\text { S. Africa }\end{array}$ & J. Roux & KU997531 & KU997289 & KU997604 \\
\hline N. vitifusiforme & CBS 110880 & STE-U5050 & V. vinifera & $\begin{array}{l}\text { Stellenbosch, } \\
\text { Western Cape, S. } \\
\text { Africa }\end{array}$ & J. van Niekerk & AY343382 & AY343344 & \\
\hline N. vitifusiforme & CBS 110887 & STE-U5252 & V. vinifera & $\begin{array}{l}\text { Stellenbosch, } \\
\text { Western Cape, S. } \\
\text { Africa }\end{array}$ & J. van Niekerk & AY343383 & AY343343 & \\
\hline N. vitifusiforme & CMW 24068 & & $\begin{array}{l}\text { S. birrea } \\
\text { subsp. } \\
\text { caffra }\end{array}$ & $\begin{array}{l}\text { Kruger National } \\
\text { Park, Mpumalanga } \\
\text { Province, S. Africa }\end{array}$ & B. Hinze & KU997329 & KU997092 & \\
\hline N. vitifusiforme & CMW 24077 & & $\begin{array}{l}\text { S. birrea } \\
\text { subsp. } \\
\text { caffra }\end{array}$ & $\begin{array}{l}\text { Kruger National } \\
\text { Park, Mpumalanga } \\
\text { Province, S. Africa }\end{array}$ & B. Hinze & KU997336 & KU997093 & \\
\hline N. vitifusiforme & CMW 24112 & & $\begin{array}{l}\text { S. birrea } \\
\text { subsp. } \\
\text { caffra }\end{array}$ & $\begin{array}{l}\text { Zululand, } \\
\text { KwaZulu-Natal, S. } \\
\text { Africa }\end{array}$ & B. Hinze & KU997363 & KU997104 & \\
\hline N. vitifusiforme & CMW 24117 & & $\begin{array}{l}\text { S. birrea } \\
\text { subsp. }\end{array}$ & $\begin{array}{l}\text { Zululand, } \\
\text { KwaZulu-Natal, S. }\end{array}$ & B. Hinze & KU997367 & KU997107 & \\
\hline
\end{tabular}




\begin{tabular}{|c|c|c|c|c|c|c|c|}
\hline & & & caffra & Africa & & & \\
\hline $\begin{array}{l}\text { Pseudofusicoccum } \\
\text { olivaceum }\end{array}$ & CMW 20881 & $\begin{array}{l}\text { CBS } \\
124939\end{array}$ & $\begin{array}{l}\text { Pterocarpus } \\
\text { angolensis }\end{array}$ & $\begin{array}{l}\text { Mawewe Nature } \\
\text { Reserve, S. Africa }\end{array}$ & $\begin{array}{l}\text { J. Mehl \& J. } \\
\text { Roux }\end{array}$ & FJ888459 & FJ888437 \\
\hline Ps. olivaceum & CMW 22637 & $\begin{array}{l}\text { CBS } \\
124940\end{array}$ & $\begin{array}{l}\text { Pt. } \\
\text { angolensis }\end{array}$ & $\begin{array}{l}\text { Pretoriuskop, } \\
\text { Kruger National } \\
\text { Park, S. Africa }\end{array}$ & J. Roux & FJ888462 & FJ888438 \\
\hline Ps. olivaceum & & MAN22138 & M. indica & $\begin{array}{l}\text { Hoedspruit- } \\
\text { Klaserie Road, } \\
\text { Limpopo Province, } \\
\text { S. Africa }\end{array}$ & J. Roux & KU997555 & KU997316 \\
\hline Ps. olivaceum & & MAN22312 & M. indica & $\begin{array}{l}\text { Hoedspruit- } \\
\text { Klaserie Road, } \\
\text { Limpopo Province, } \\
\text { S. Africa }\end{array}$ & J. Roux & KU997461 & KU997238 \\
\hline
\end{tabular}




\section{Table 2}

\begin{tabular}{llll}
\hline Locus & S. birrea & M. indica & Combined \\
\hline Number of isolates & 27 & 51 & 78 \\
Alleles observed & 19 & 25 & 25 \\
Private alleles observed & 0 & 6 & \\
Gene diversity $\left(H_{\mathrm{s}}\right)$ & 0.513 & 0.526 & 0.519 \\
Genotypic diversity* & & & \\
Observed & $0.493, P=0.419$ & $0.330, P=0.070$ & $0.383, P=0.159$ \\
Expected & 0.535 & 0.554 & 0.554 \\
Index of association $\left(\mathrm{I}_{\mathrm{A}}\right)$ & & & \\
$\quad$ & $0.422, P=0.001$ & $0.384, P<0.001$ & $0.380, P<0.001$ \\
$\quad \begin{array}{l}\text { Observed } \\
\quad \text { Range }\end{array}$ & $-0.298-0.483$ & $-0.217-0.275$ & $-0.157-0.206$ \\
Linkage disequilibrium $(\mathrm{rBarD})$ & $0.109, P=0.001$ & $0.083, P<0.001$ & $0.080, P<0.001$ \\
$\quad$ Observed & $-0.077-0.125$ & $-0.047-0.059$ & $-0.033-0.043$ \\
$\quad$ Range & &
\end{tabular}

${ }^{*}$ Genotypic diversities were computed prior to clone-correction. 
Table 3

\begin{tabular}{llll}
\hline Source of variation & Sum of squares & $\begin{array}{l}\text { Variance } \\
\text { components }\end{array}$ & Percentage variation \\
\hline Among populations & 467.158 & 4.674 & 6.4 \\
Among individuals & 10418.431 & 68.542 & 93.6 \\
within populations & & & 100 \\
Total & 10885.589 & 73.216 & \\
\hline
\end{tabular}




\begin{tabular}{|c|c|c|c|c|}
\hline Year & Host & Site & Species & Isolates \\
\hline \multirow[t]{19}{*}{2006} & S. birrea & Hans Merensky Estate & Lasiodiplodia theobromae & 1 \\
\hline & & Kruger National Park & N. mediterraneum & 8 \\
\hline & & & N. vitifusiforme & 30 \\
\hline & & Lakelands & Diplodia allocellula & 2 \\
\hline & & & L. crassispora & 1 \\
\hline & & & L. gonubiensis & 3 \\
\hline & & & L. iraniensis & 8 \\
\hline & & & L. theobromae & 1 \\
\hline & & & N. mediterraneum & 1 \\
\hline & & & N. vitifusiforme & 7 \\
\hline & M. & Hans Merensky Estate & Botryosphaeria fabicerciana & 2 \\
\hline & indica & & & \\
\hline & & & L. mahajangana & 1 \\
\hline & & & L. pseudotheobromae & 2 \\
\hline & & & L. theobromae & 2 \\
\hline & & & N. australe & 1 \\
\hline & & & N. kwambonambiense & 6 \\
\hline & & & N. parvum & 114 \\
\hline & & & N. umdonicola & 13 \\
\hline \multirow[t]{12}{*}{2012} & S. birrea & Hoedspruit & B. fabicerciana & 1 \\
\hline & & & L. mahajangana & 1 \\
\hline & & & L. pseudotheobromae & 1 \\
\hline & & & N. parvum & 29 \\
\hline & & & N. umdonicola & 2 \\
\hline & $M$ & Hoedspruit & B. fabicerciana & 3 \\
\hline & indica & & & \\
\hline & & & N. kwambonambiense & 8 \\
\hline & & & N. mediterraneum & 1 \\
\hline & & & N. parvum & 137 \\
\hline & & & N. umdonicola & 12 \\
\hline & & & Pseudofusicoccum olivaceum & 2 \\
\hline
\end{tabular}




\begin{tabular}{|c|c|c|c|c|}
\hline Locus & Allele & S. birrea & M. indica & Combined \\
\hline \multirow[t]{4}{*}{ BotF11 } & 420 & 0.050 & 0.026 & 0.034 \\
\hline & 429 & $0.700^{+}$ & $0.923^{+}$ & $0.847^{+}$ \\
\hline & 433 & 0.250 & 0.051 & 0.119 \\
\hline & Null & 0.259 & 0.235 & 0.244 \\
\hline \multirow[t]{9}{*}{ BotF17* } & 1 & 0.125 & $0.306^{+}$ & $0.247^{+}$ \\
\hline & 2 & 0 & 0.082 & 0.055 \\
\hline & 3 & 0.292 & 0.061 & 0.137 \\
\hline & 4 & 0.167 & 0.184 & 0.178 \\
\hline & 5 & 0 & 0.102 & 0.068 \\
\hline & 6 & $0.333^{+}$ & 0.184 & 0.233 \\
\hline & 7 & 0.083 & 0.061 & 0.068 \\
\hline & 8 & 0 & 0.020 & 0.014 \\
\hline & Null & 0.111 & 0.039 & 0.064 \\
\hline \multirow[t]{4}{*}{ BotF18 } & 234 & $0.560^{+}$ & $0.370^{+}$ & $0.437^{+}$ \\
\hline & 244 & 0.320 & 0.326 & 0.324 \\
\hline & 250 & 0.120 & 0.304 & 0.239 \\
\hline & Null & 0.074 & 0.098 & 0.090 \\
\hline \multirow[t]{3}{*}{ BotF21 } & 211 & $1^{+}$ & $0.818^{+}$ & $0.879^{+}$ \\
\hline & 221 & 0 & 0.182 & 0.121 \\
\hline & Null & 0.185 & 0.137 & 0.154 \\
\hline \multirow[t]{3}{*}{ BotF23 } & 424 & $0.520^{+}$ & $0.784^{+}$ & $0.697^{+}$ \\
\hline & 427 & 0.480 & 0.216 & 0.303 \\
\hline & Null & 0.074 & 0 & 0.026 \\
\hline \multirow[t]{8}{*}{ BotF35* } & 1 & 0.182 & 0.071 & 0.120 \\
\hline & 2 & 0 & 0.143 & 0.080 \\
\hline & 3 & 0.091 & 0.071 & 0.080 \\
\hline & 4 & $0.545^{+}$ & 0.214 & $0.360^{+}$ \\
\hline & 5 & 0 & 0.071 & 0.040 \\
\hline & 6 & 0.091 & $0.357^{+}$ & 0.240 \\
\hline & 7 & 0.091 & 0.071 & 0.080 \\
\hline & Null & 0.593 & 0.725 & 0.679 \\
\hline
\end{tabular}

${ }^{+}$Dominant allele at each locus

*Alleles at these loci were sequenced and the different genotypes observed are denoted by numbers $1-8$. 


\begin{tabular}{lllll}
\hline Iteration & \multicolumn{4}{l}{ Source population $\rightarrow$ destination population $( \pm$ standard error) } \\
\hline & S. birrea $\rightarrow S$. & $S$. birrea $\rightarrow M$. & $M$. indica $\rightarrow M$. & M. indica $\rightarrow S$. \\
& birrea & indica & indica & birrea \\
1 & $0.884 \pm 0.004$ & $0.117 \pm 0.004$ & $0.375 \pm 0.005$ & $0.625 \pm 0.005$ \\
2 & $0.884 \pm 0.004$ & $0.117 \pm 0.004$ & $0.375 \pm 0.005$ & $0.625 \pm 0.005$ \\
3 & $0.883 \pm 0.004$ & $0.117 \pm 0.004$ & $0.374 \pm 0.005$ & $0.626 \pm 0.005$ \\
4 & $0.883 \pm 0.004$ & $0.117 \pm 0.004$ & $0.374 \pm 0.005$ & $0.626 \pm 0.005$ \\
5 & $0.883 \pm 0.004$ & $0.117 \pm 0.004$ & $0.374 \pm 0.005$ & $0.626 \pm 0.005$ \\
6 & $0.884 \pm 0.004$ & $0.116 \pm 0.004$ & $0.379 \pm 0.008$ & $0.621 \pm 0.008$ \\
7 & $0.883 \pm 0.004$ & $0.117 \pm 0.004$ & $0.374 \pm 0.005$ & $0.627 \pm 0.005$ \\
8 & $0.884 \pm 0.004$ & $0.116 \pm 0.004$ & $0.378 \pm 0.007$ & $0.622 \pm 0.007$ \\
9 & $0.793 \pm 0.022$ & $0.207 \pm 0.022$ & $0.453 \pm 0.020$ & $0.547 \pm 0.020$ \\
10 & $0.883 \pm 0.004$ & $0.117 \pm 0.004$ & $0.375 \pm 0.005$ & $0.625 \pm 0.005$ \\
Average & $0.875 \pm 0.006$ & $0.126 \pm 0.006$ & $0.383 \pm 0.007$ & $0.617 \pm 0.007$ \\
\hline
\end{tabular}




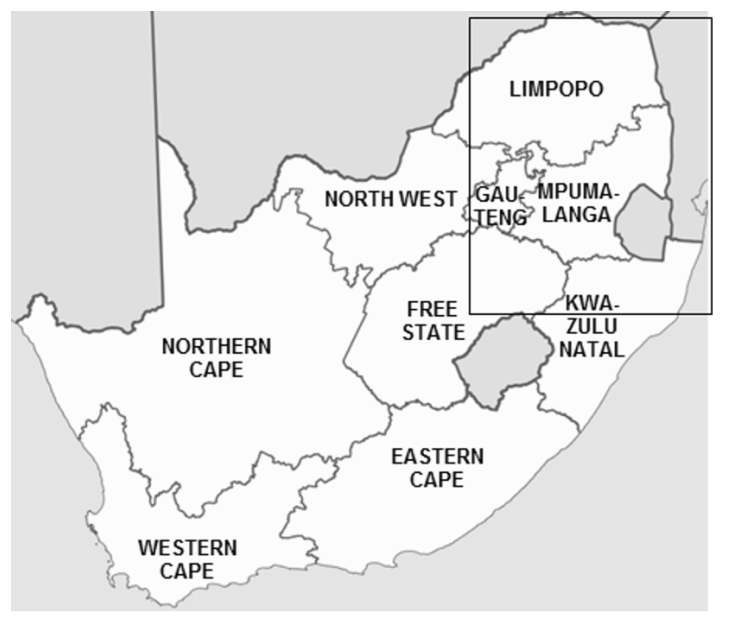

Botryosphaeria fabicerciana

Diplodia allocellula

Lasiodiplodia crassispora

Lasiodiplodia gonubiensis

Lasiodiplodia iraniensis

Lasiodiplodia mahajangana

Lasiodiplodia pseudotheobromae

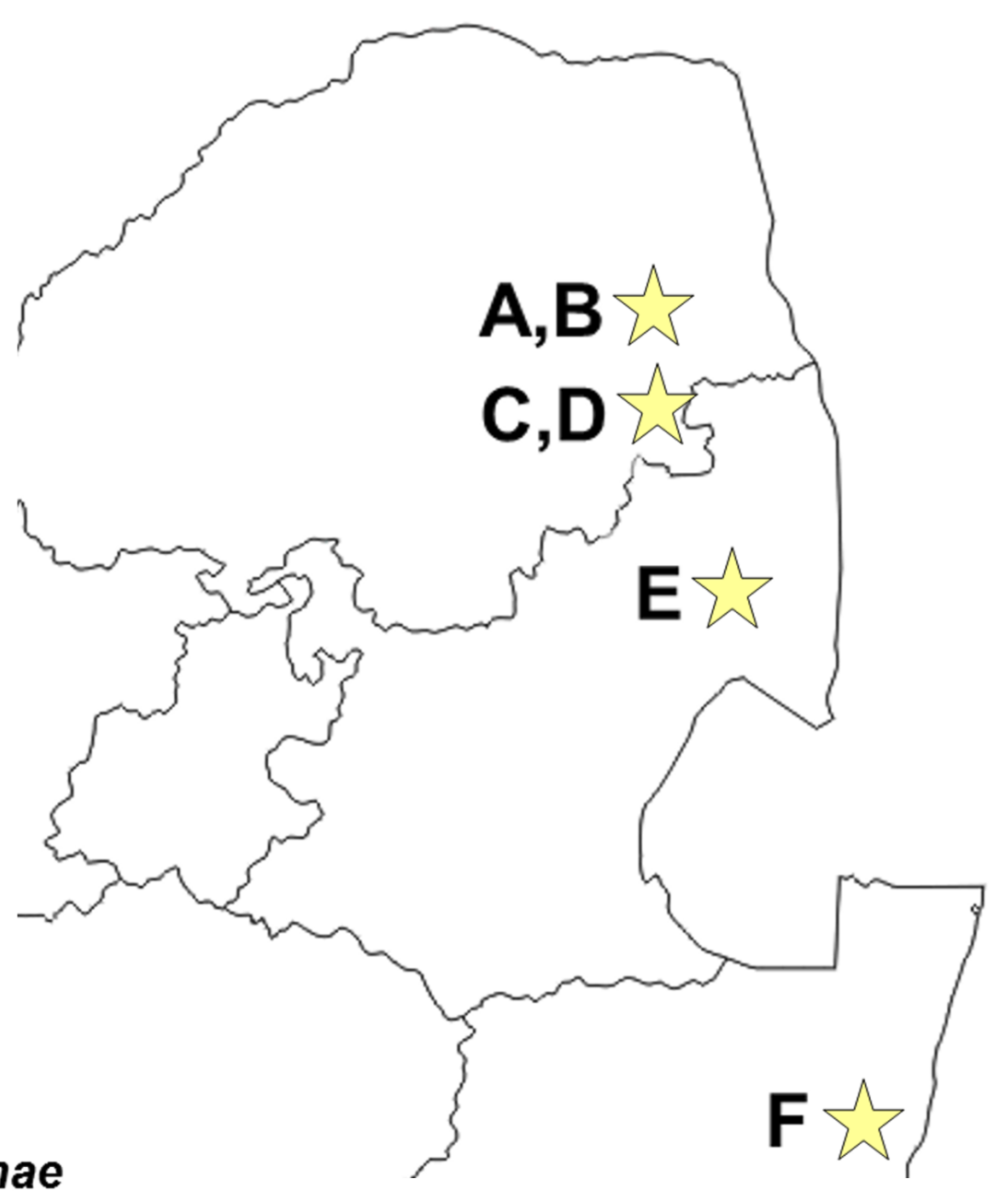

Lasiodiplodia theobromae

Neofusicoccum australe

Neofusicoccum kwambonambiense

A. Hans Merensky

Estate,

Neofusicoccum mediterraneum

Neofusicoccum parvum

Neofusicoccum umdonicola

Neofusicoccum vitifusiforme

Pseudofusicoccum olivaceum

C. Hoedspruit, Marula $(n=34)$

D. Hoedspruit, Mango $(n=163)$ Marula $(n=1)$

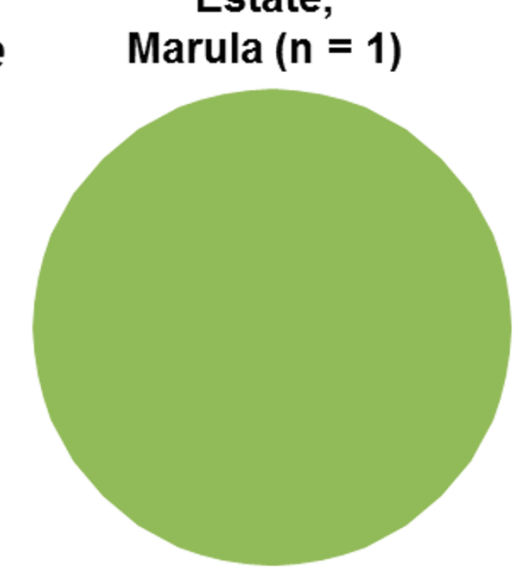

E. Kruger National Park, Marula $(n=38)$
B. Hans Merensky Estate, Mango $(n=141)$

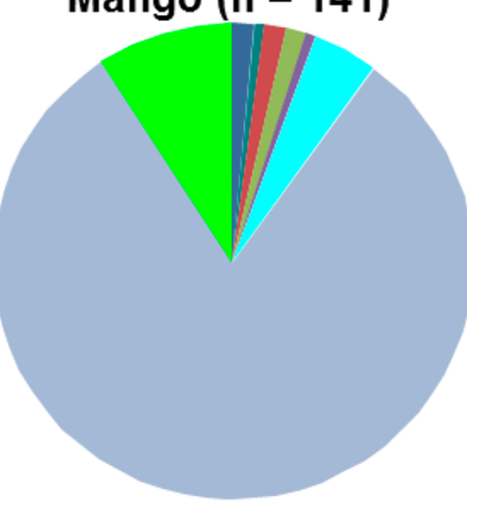

F. Lakelands, Mfolozi Village, Marula $(n=23)$
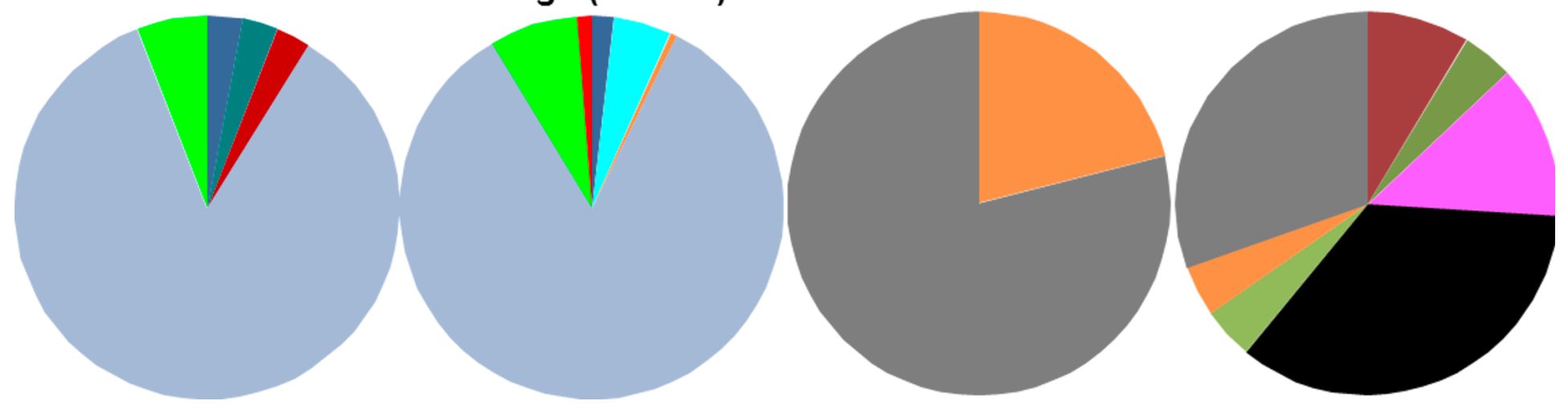


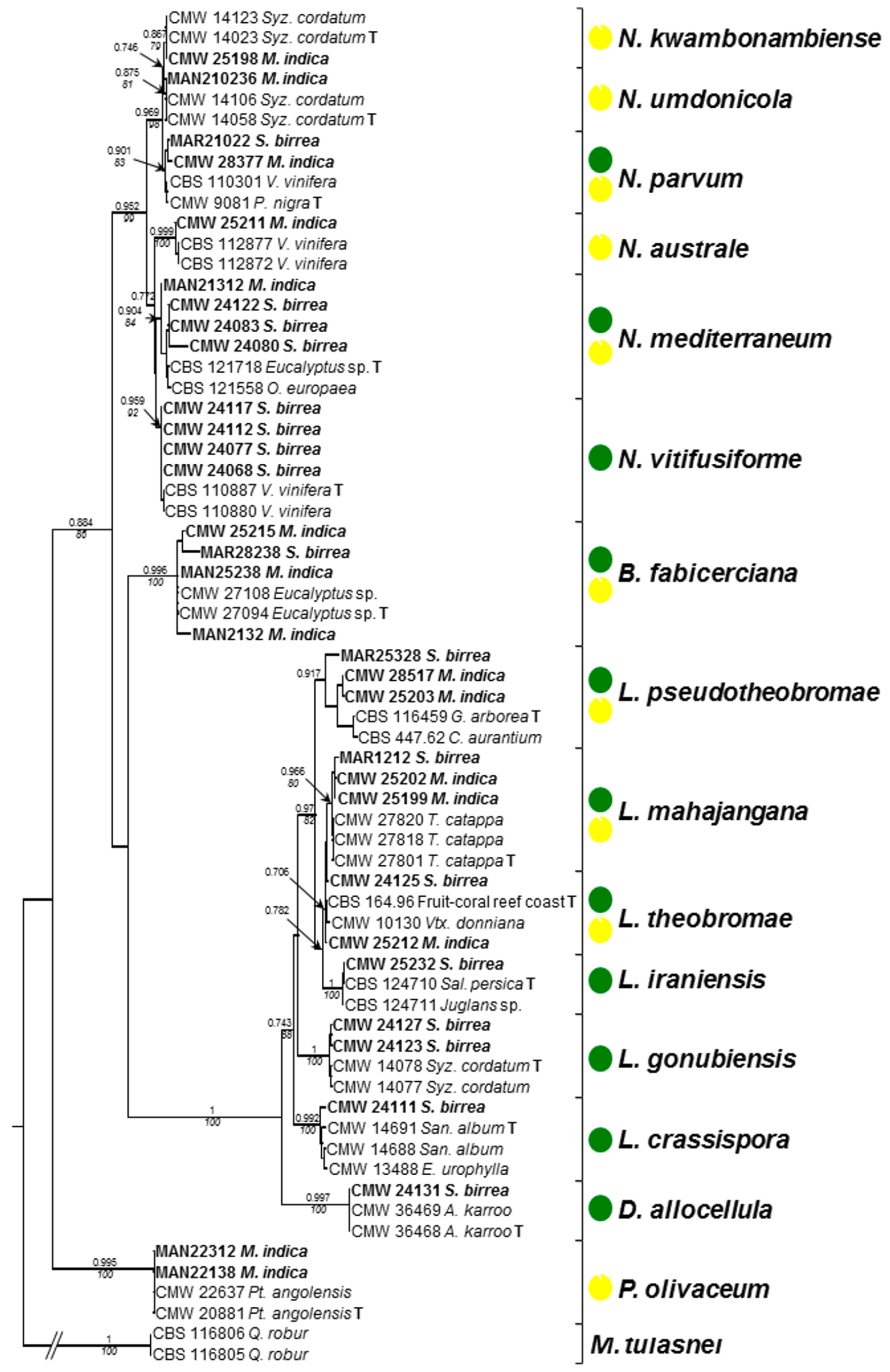



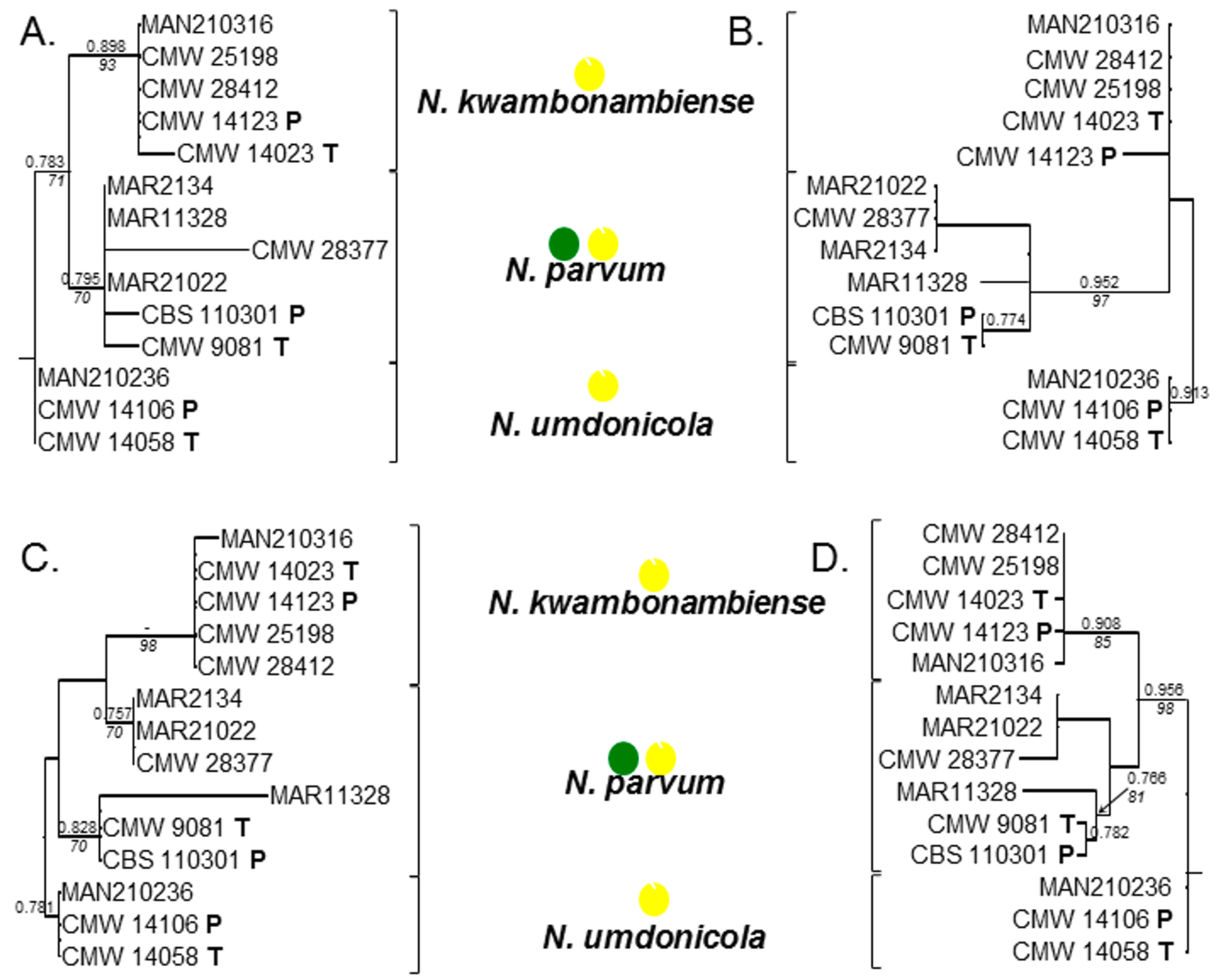


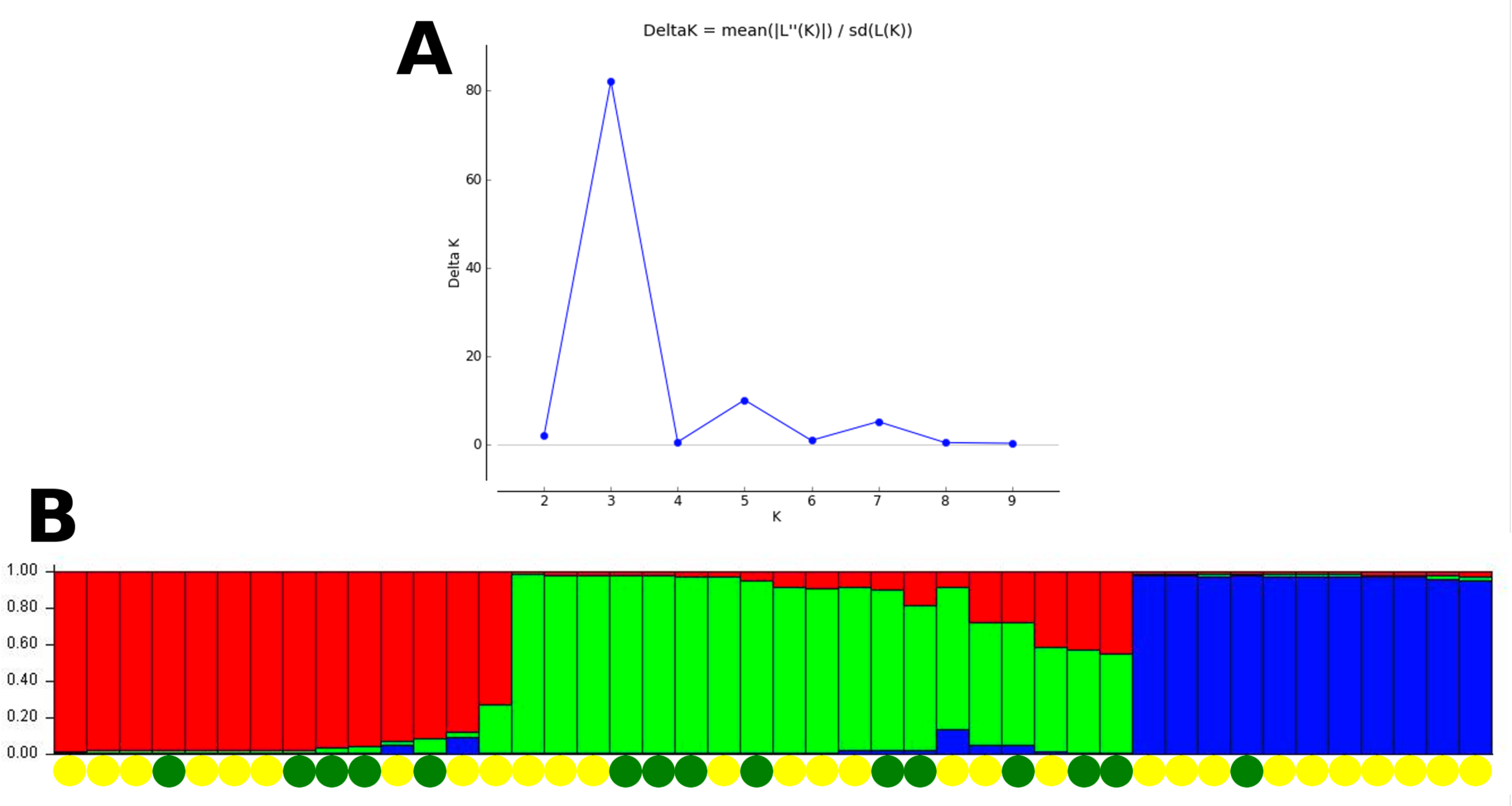




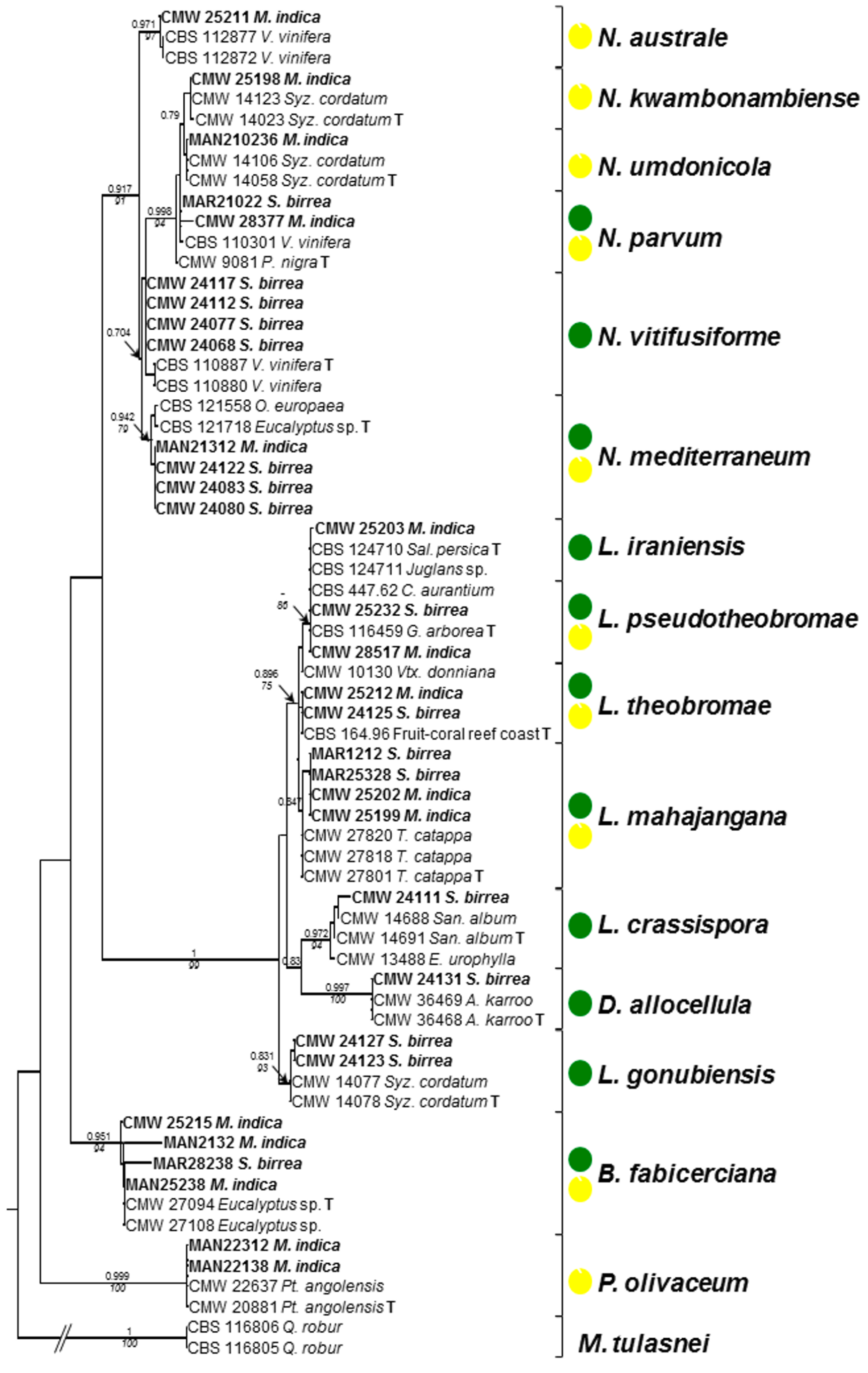




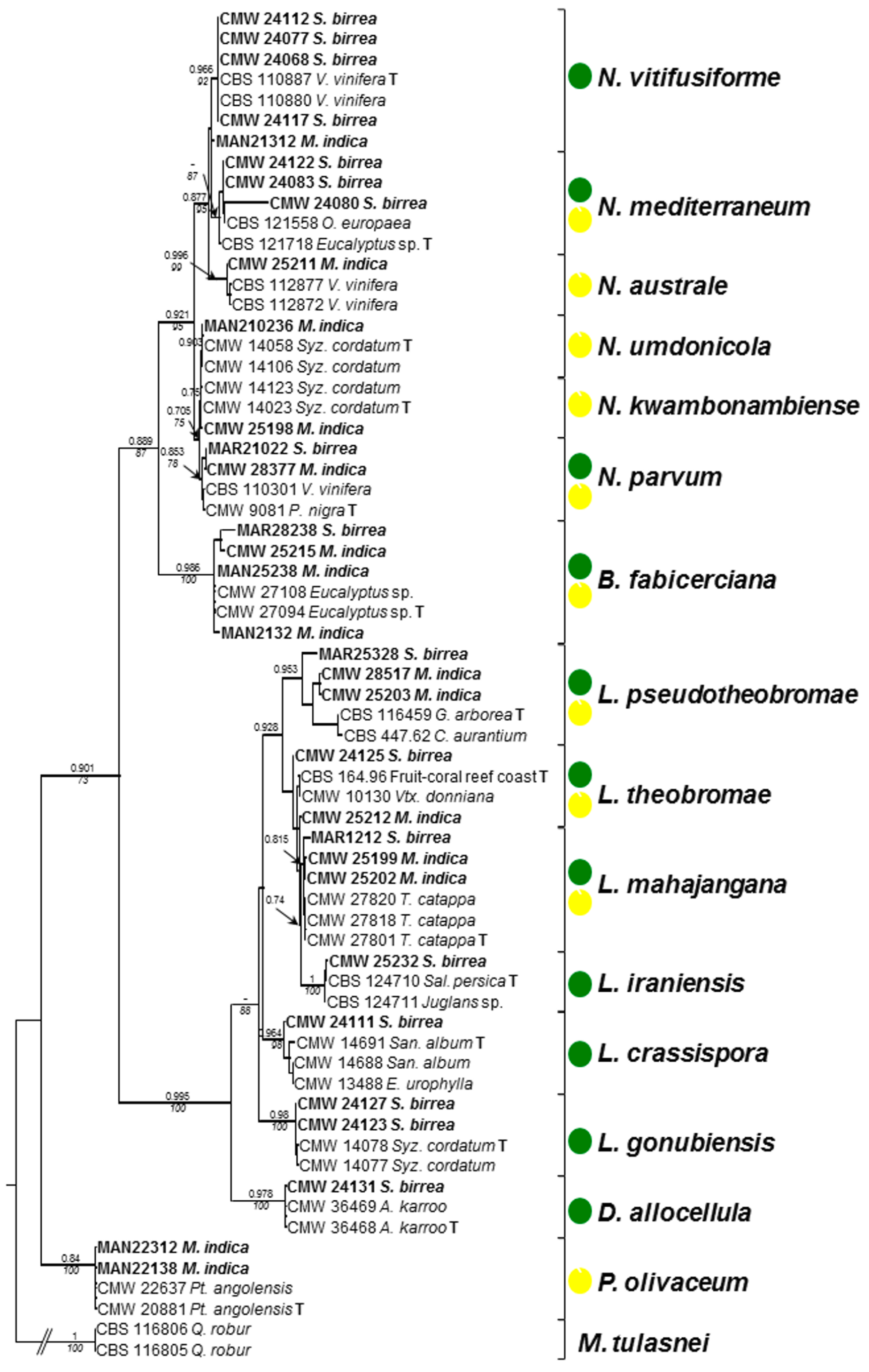

